\title{
THE PORTAGE LAKE VOLCANICS
}

(MIDDLE KEWEENAWAN)

ON ISLE ROYALE,

\section{MICHIGAN}

Prepared in cooperation with the

National Park Service 



\section{The Portage Lake Volcanics}

(Middle Keweenawan) on

Isle Royale, Michigan

By N. KING HUBER

\section{GEOLOGY OF ISLE ROYALE NATIONAL PARK, MICHIGAN}

GEOLOGICAL SURVEY PROFESSIONALA P P R 754 - C

Prepared in cooperation with

the National Park Service

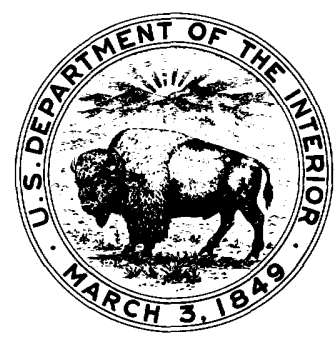




\title{
UNITED STATES DEPARTMENT OF THE INTERIOR
}

ROGERS C. B. MORTON, Secretary

\section{GEOLOGICAL SURVEY}

\author{
V. E. McKelvey, Director
}

Library of Congress catalog-card No. 73-600161

For sale by the Superintendent of Documents, U.S. Government Printing Office Washington, D.C. 20402 - Price $\$ 1.05$ (paper cover)

Stock Number 2401-02399 


\section{CONTENTS}

\begin{tabular}{|c|c|c|c|}
\hline Abstract & Page & The Portage Iake Volcanic & Page \\
\hline Introduction & 1 & Volcanic rocks-Continued & \\
\hline Historical background & 1 & Stratigraphic units-Continued & \\
\hline Scope of study & 1 & 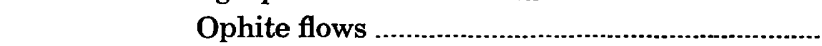 & C18 \\
\hline Acknowledgments & 2 & Greenstone Flow & 19 \\
\hline The Portage Lake Volcanics on the Keweenaw Peninsula .. & 3 & Hill Point Flow .. & 19 \\
\hline $\begin{array}{l}\text { the Portage Lake Volcanics on Isle Royale } \\
\text { General description }\end{array}$ & $\begin{array}{l}4 \\
4\end{array}$ & Washington Islar & 20 \\
\hline Volcanic rocks & 5 & Sedimentary rocks & 20 \\
\hline 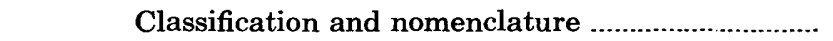 & 5 & Pyroclastic rocks & 22 \\
\hline Compositior & 7 & Stratigraphic summary & 23 \\
\hline Stratigra & 8 & Stratigraphic thickness & 23 \\
\hline Porphyrite flows & 13 & Correlations & 24 \\
\hline $\begin{array}{l}\text { Scoville Point, Middle Point, and } \\
\text { Tobin Harbor Flows }\end{array}$ & 13 & Correlation betwee & \\
\hline Huginnin and Grace Island Flows ............ & 13 & eolotiontos & \\
\hline Trap flows & 15 & Kelation to 0 & \\
\hline Edwards Island and Long Island Flows .. & 15 & Structure ........................ & \\
\hline Amygdaloid Island Flow. & 18 & References cited & 30 \\
\hline
\end{tabular}

\section{ILLUSTRATIONS}

FIGURE 1. Sketch map showing generalized distribution of Keweenawan rocks in the Lake Superior region

2. Chart showing nomenclature for middle and upper Keweenawan rocks of northern Michigan and adjacent parts of Wisconsin

3. Longitudinal stratigraphic section of the Portage Lake Volcanics on the Keweenaw Peninsula

4. Photographs showing characteristic textures of volcanic rocks on Isle Royale

5. Photograph showing coarse ophite with knobby weathered surface

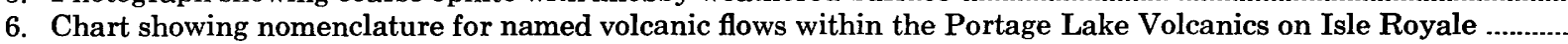

7. Plot showing tholeiitic affinities of analyzed specimens of rocks from the Portage Lake Volcanics on Isle Royale

8. Plot illustrating the predominantly basaltic nature of analyzed specimens of rocks from the Portage Lake Volcanics on Isle Royale

9. Shaded-relief map of Isle Royale National Park ...

10. Schematic columnar section of the Portage Lake Volcanics on Isle Royale .

11. Simplified map of bedrock geology of Isle Royale

12-16. Photographs showing:

12. Porphyrite from Huginnin Flow

13. Beach cobble of porphyrite from Grace Island Flow

14. Columnar jointing in Edwards Island Flow.

15. Specimen of Amygdaloid Island Flow with characteristic agate amygdules

16. Specimen of ophite from Washington Island Flow

17. Columnar section of upper part of Portage Lake Volcanics showing distribution of sedimentary units in the Chippewa Harbor area

18-21. Photographs showing:

18. Scour-and-fill structure in pebbly sandstone near the west end of Chippewa Harbor

19. Breccia occurring above the Amygdaloid Island Flow

20. Tuff-breccia overlying the Greenstone Flow.

21. Agates typical of those occurring in the tuff-breccia overlying the Greenstone Flow

22. Geologic section of Isle Royale in the vicinity of Lake Desor and Houghton Ridge

23. Longitudinal stratigraphic section showing variations in thickness of the Portage Lake Volvanics on Isle Royale

24. Stratigraphic diagram illustrating correlation of sedimentary horizons in the Portage Lake Volcanics between Isle Royale and the Keweenaw Peninsula

19

19

20

20 


\section{TABLES}

1. Analyses of volcanic rocks of the Portage Lake Volcanics, Isle Royale

2. Correlation of clastic units in the Portage Lake Volcanics between the Keweenaw Peninsula and Isle Royale

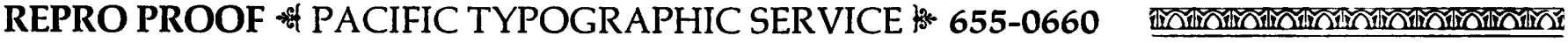




\title{
THE PORTAGE LAKE VOLCANICS (MIDDLE KEWEENAWAN) ON ISLE ROYALE, MICHIGAN
}

\author{
By N. KING Huber
}

\begin{abstract}
The Portage Lake Volcanics is the upper part of the total volcanic sequence of Keweenawan (Precambrian) age in the Lake Superior region. On Isle Royale the formation consists of more than 10,000 feet of basaltic and andesitic lava flows with interbedded pyroclastic rocks and fluvially deposited sedimentary rocks. Certain stratigraphic units representing flows or groups of flows can be identified and traced in the field on the basis of their texture or other distinctive characteristics. Twelve such flow units have been distinguished and named on the island, and these key units provide stratigraphic and structural control within the volcanic sequence.

Correlation between the Portage Lake Volcanics on Isle Royale and the type area some 50 miles southeast on the Keweenaw Peninsula on the opposite side of the Lake Superior syncline is excellent, and at least one individual lava flow is interpreted as being continuous across the basin.

The Portage Lake Volcanics on Isle Royale does not appear to stratigraphically overlap the lower part of the Keweenawan volcanic sequence on the north side of the syncline, represented by the North Shore Volcanic Group in Minnesota, and there may be a stratigraphic break between them. The North Shore Volcanic Group is the source terrane for most of the clastic debris in the interbedded sedimentary rocks in the Portage Lake Volcanics on Isle Royale as well as in the overlying Copper Harbor Conglomerate.

The flood basalts of the Portage Lake Volcanics were erupted from a major rift zone of continental proportions that trends in an arc through Lake Superior. Similar flood basalts underlie most or all of a belt nearly 100 miles wide and more than 1,000 miles long. The depositional basin was subsiding as it was being filled, and during intermittent periods of volcanic quiescence, clastic debris was swept into the basin from its margins to form the sedimentary deposits interbedded with the lava flows. When volcanism ceased, subsidence continued, permitting the accumulation of a thick sedimentary sequence, the Copper Harbor Conglomerate and younger Keweenawan sedimentary rocks.
\end{abstract}

\section{INTRODUCTION}

\section{HISTORICAL BACKGROUND}

It has long been proposed that part of the rock sequence on the Keweenaw Peninsula extends beneath the Lake Superior basin and is exposed again on Isle Royale (fig. 1). The basis for this interpretation is the similarity of the volcanic and sedimentary rock types and of the gross stratigraphic succession in both areas. As early as 1849, Charles T. Jackson (p. 474) stated that "this island has the same geological character as Keweenaw Point, and is of the same geological age." And in 1850, John W. Foster and Josiah D. Whitney (p. 81) noted that "in many respects, Isle Royale may be regarded as the counterpart of Keweenaw Point."

Although the reconnaissance surveys of Jackson, Foster, and Whitney led to the first suggestions of correlation between the stratigraphic sections of Isle Royale and the Keweenaw Peninsula, not until the investigations of Alfred C. Lane $(1898 ; 1911)$ was a firm foundation provided for such correlations by the recognition of parallel sequences of the varied rock types. Lane $(1898$, p. 101) concluded that "on the whole the coincidence is fairly satisfactory, and warrants us in saying that we have represented on Isle Royale practically the whole of the Copper Range [Portage Lake Volcanics] as it exists from the Central Mine to Portage Lake," on the Keweenaw Peninsula. Since Lane's study, no additional data regarding the Portage Lake Volcanics on Isle Royale have been published.

\section{SCOPE OF STUDY}

The present report, a part of a general study of the geology of Isle Royale National Park being carried out in cooperation with the National Park Service, focuses on the stratigraphy and structure of the Portage Lake Volcanics on Isle Royale and presents additional data on correlations with the Keweenaw Peninsula and on relations to other volcanic sequences of Keweenawan age. Only compositional and petrologic data necessary to characterize the rocks are given, as the rocks are similar in all respects to rocks of the Portage Lake Volcanics on the Keweenaw Peninsula and details can be obtained from extensive studies of those rocks on the peninsula. An earlier companion report describes the overlying Copper Harbor Conglomerate on Isle Royale 


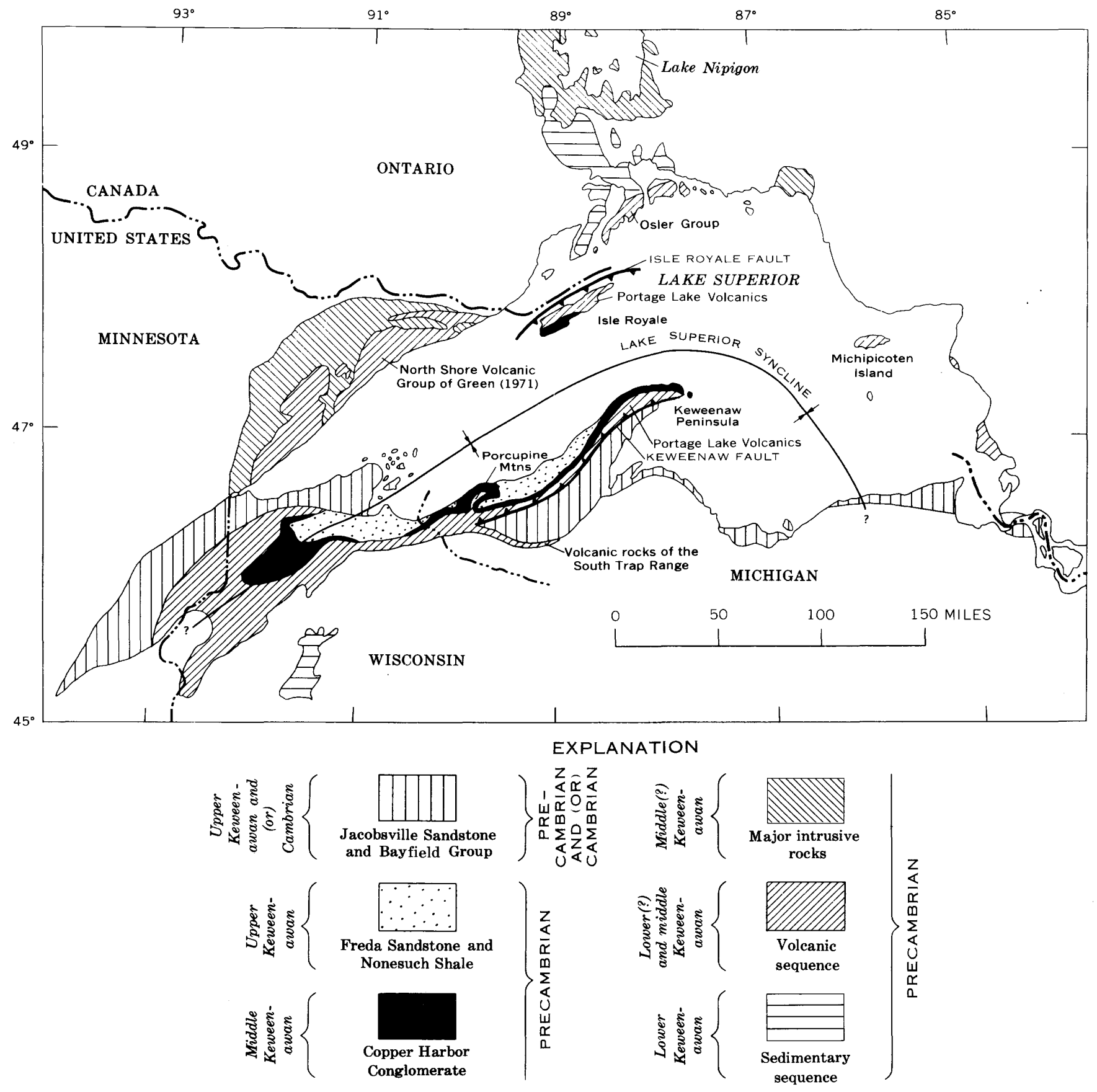

FiguRE 1.-Generalized distribution of Keweenawan rocks in the Lake Superior region. Data from Green (1971), Halls (1966), Halls and West (1971), Irving (1883), White (1966a), and White and Wright (1960).

(Wolff and Huber, 1973). A geologic map of Isle Royale National Park at a scale of 1:62,500, published separately (Huber, 1973b), provides details of the distribution and structure of the Portage Lake Volcanics not possible to show at the scale of maps in the present report, and it is recommended that that map be used in conjunction with this report. In fact, some of the place names mentioned in this report can be found only on that geologic map or on the Topographic Map of
Isle Royale National Park (U.S. Geological Survey, 1957).

\section{ACKNOWLEDGMENTS}

The generous support of the National Park Service staff made this study possible. Numerous discussions with Henry R. Cornwall and Walter S. White, drawing upon their extensive knowledge of the geology of the Keweenaw Peninsula, were very helpful. Field visits with John C. Green, Harold A. Hubbard, and Walter S. 
White, in their respective areas of Keweenawan study, have been of help in understanding the regional aspects of Keweenawan geology. During summers on the island, I was ably assisted, successively, by Robert J. Larson, Harrison T. Southworth, Charles E. Bartberger, and David R. Chivington.

\section{THE PORTAGE LAKE VOLCANICS ON THE KEWEENAW PENINSULA}

The middle Keweenawan (Precambrian) Portage Lake Volcanics, in its type area on the Keweenaw Peninsula, is made up of a sequence of several hundred lava flows with rhyolite conglomerate separating some of the flows. Interbedded sandstone and pyroclastic rocks are less abundant. Since the first significant geologic account of the native-copper deposits in the Portage Lake Volcanics by Houghton (1841), the formation has been intensively studied by many workers. Although the latest comprehensive report is that of Butler and Burbank (1929), much of the more recent literature is covered in a review of the Keweenawan geology of the Lake Superior region by Halls (1966) and in papers on the geology of the Michigan copper district by White $(1968,1971)$. These reports are the source of most of the material in the following summary.

The formation name Portage Lake Lava Series was introduced (White and others, 1953) as a comprehensive name to include rocks designated the Bohemian Range, Central Mine, Ashbed, and Eagle River Groups of earlier reports. (See Lane, 1911; Butler and Burbank, 1929, p. 17-18.) At the request of the Geologic Names Committee of the U.S. Geological Survey and in consultation with workers in the type area (W. S. White, written commun., 1972), the formation name Portage Lake Volcanics is used in this report in place of Portage Lake Lava Series in order to bring the formation name into conformity with the Code of Stratigraphic Nomenclature (American Commission on Stratigraphic Nomenclature, 1970, p. 7, 14). The formation is locally at least 15,000 feet thick on the Keweenaw Peninsula, but the base is nowhere exposed because the lower part of the sequence is bounded by a high-angle thrust fault, the Keweenaw fault. In westernmost Michigan, structural considerations suggest that the Portage Lake Volcanics unconformably overlies older Keweenawan volcanic rocks, which form the so-called South Trap Range (Hubbard, 1968). The Portage Lake Volcanics is conformably overlain by the Copper Harbor Conglomerate, which White (1972) proposed be reassigned from the upper to the middle Keweenawan. Locally the two formations are interfingered (fig. 2). The Copper Harbor Conglomerate is overlain by the upper Keweenawan Nonesuch Shale and Freda Sandstone of the Oronto Group.

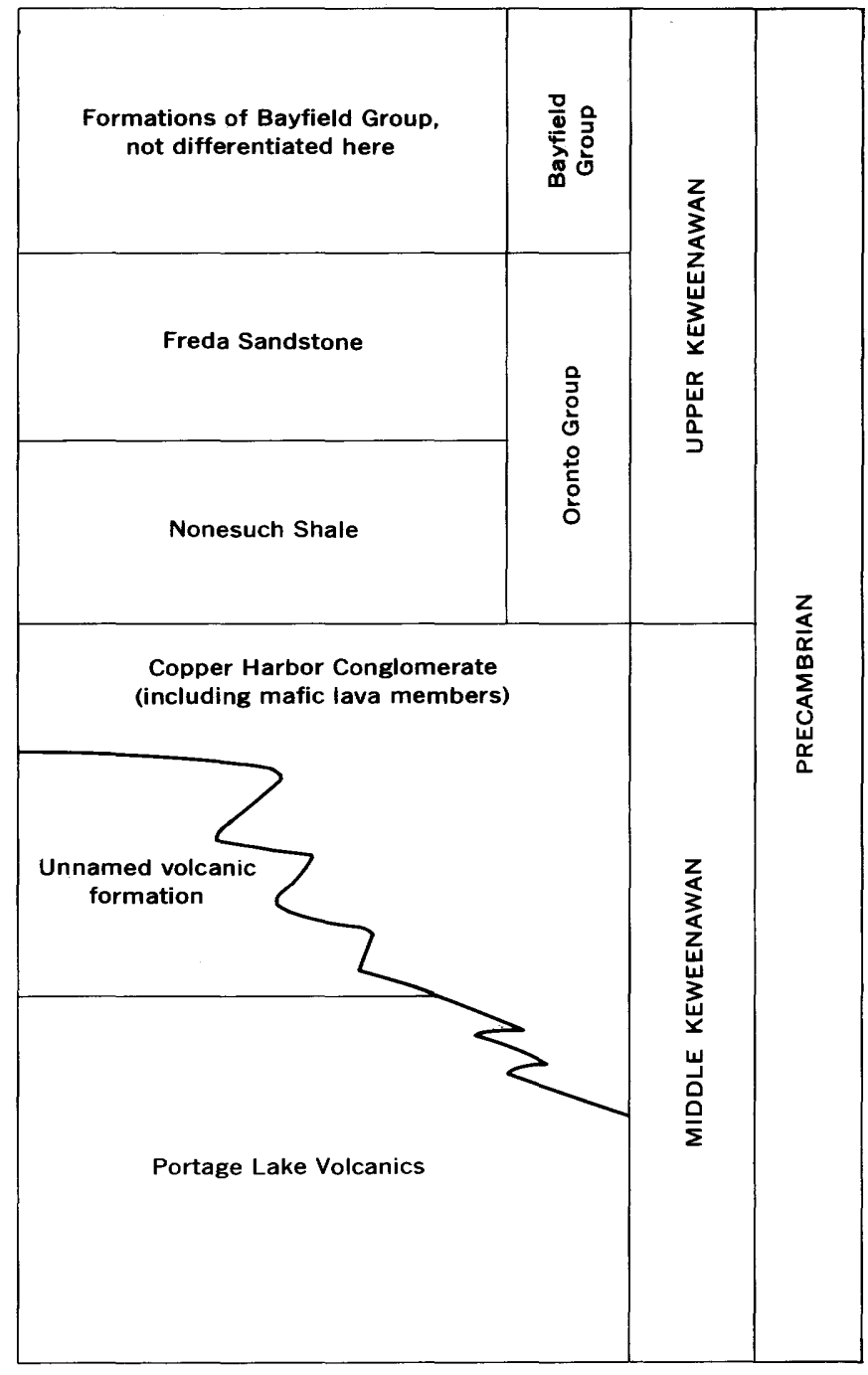

FIGURE 2.-Nomenclature for middle and upper Keweenawan rocks of northern Michigan and adjacent parts of Wisconsin (from White, 1972). The unnamed volcanic formation occurs only in the Porcupine Mountains area (fig. 1).

The lava flows are predominantly basalt or basaltic andesite, containing essential calcic plagioclase (generally labradorite), augite, and minor olivine. Compositional details of the volcanic rocks have been summarized most completely by Broderick (1935) and by Cornwall (1951a; 1951b). About 40 percent of the mafic flows have ophitic texture, coarsest in the thickest flows. The remaining flows are quite fine grained but show textural differences that depend mostly upon feldspar grain size and distribution. The uppermost 5-20 percent of most individual lava flows is conspicuously amygdaloidal and contains 5-50 percent vesicles filled with secondary minerals. The abundance of amygdules decreases downward toward the amygdule-free massive basalt of the middle and lower part of the flow. A thin amygdaloidal zone is generally 
present at the base. In many of the flow tops, the vesicular crust was brecciated, probably during flow, and now consists of rubbly or fragmental material in which both amygdules within fragments and interstices between fragments are filled with secondary minerals. Many of the thicker flows have undergone magmatic differentiation, with the development of an internal zone having layers characterized by a pegmatitic texture; the Greenstone Flow is a prime example. Rhyolite flows or domes are present locally but are uncommon.

The interbedded conglomerates are thoroughly lithified and normally consist of subangular to rounded pebbles, cobbles, or boulders of rhyolite and subordinate basalt in a sand matrix. Locally, granophyre pebbles are abundant. Individual beds of conglomerate or sandstone range from less than 1 inch to more than 100 feet in thickness and tend to be lenticular. Some individual lava flows and most of the major interbedded conglomerate units can be traced for many miles along strike. They thus provide useful stratigraphic marker horizons, and many have been named (and (or) numbered) for ease of reference (fig. 3 ).

Radiometric age determinations by the uranium-lead method suggest that Keweenawan igneous activity falls within the range of $1,120-1,140$ million years ago (Silver and Green, 1972). The Portage Lake Volcanics thus clearly is within a newly defined division of the Precambrian, Precambrian Y (James, 1972), which has an age range of $800-1,600$ million years.

\section{THE PORTAGE LAKE VOLCANICS ON ISLE ROYALE GENERAL DESCRIPTION}

The Portage Lake Volcanics on Isle Royale, as on the Keweenaw. Peninsula, consists of a thick sequence of basalt and basaltic andesite lava flows with inter-



Figure 3.-Longitudinal stratigraphic section of the Portage Lake Volcanics on the Keweenaw Peninsula. Conglomerate beds are numbered according to local usage (from White, 1968). 
bedded conglomerate, sandstone, and pyroclastic rocks. Exposures on the island indicate a minimum thickness of 10,000 feet, and as the base of the sequence is not exposed, the total thickness must be considerably greater. The formation is conformably overlain by the Copper Harbor Conglomerate (Wolff and Huber, 1973). The entire sequence is tilted toward the southeast at dips ranging from $55^{\circ}$ to less than $5^{\circ}$, with attitudes generally steeper on the north side of the island than on the south. Geophysical data suggest that a major high-angle thrust fault, the Isle Royale fault, lies between Isle Royale and the north shore of Lake Superior (Halls and West, 1971), thus increasing the structural similarity between Isle Royale and the Keweenaw Peninsula.

Records from holes drilled during exploration for copper suggest that there may be more than 150 flows in the section on the island (Lane, 1898), but some units indicated as individual flows in Lane's section may actually be parts of composite flows or duplications caused by faulting. In the same drill logs Lane records 25 clastic units 1 foot or more thick; less than a third of these units are known from outcrop, and those occur primarily in the uppermost part of the section.

\section{VOLCANIC ROCKS}

\section{CLASSIFICATION AND NOMENCLATURE}

The classification adopted here for the volcanic rocks of the Portage Lake Volcanics on Isle Royale is physically descriptive so as to be useful not only to the specialist but to the interested visitor to the National Park; it is based chiefly upon rock textures. Such a classification has not been widely used outside the Lake Superior region, but by 1898 , when Lane's Isle Royale report was published, a textural classification was well established in the Michigan copper district and was used by Lane, who later reviewed the history of the development of this classification (1911, p. 51-66). As emphasized by Butler and Burbank (1929, p. 23-24),

the one outstanding characteristic of the flows that is most useful in their classification is their texture, which serves as one of the major bases of correlation from section to section. Textural classification may be made in hand specimen, drill core, or outcrop. There may be some differences of opinion as to the appropriateness of the names used in this classification but there can be no doubt as to the usefulness of the distinctions.

The following textural classification, based upon Lane $(1898,1911)$, is used in this report:

Ophite.-Rock with an ophitic texture is produced by crystals of pyroxene that surround and enclose unoriented plagioclase laths, imparting a mottling (fig. $4 A$ ). Weathering commonly accentuates the texture, both by increasing color contrast between the pyroxene crystals and the rock matrix and by producing a knobby surface (fig. 5). In freshly broken rock the texture can be distinguished by the flashing of pyroxene cleavage faces. The size of the pyroxene crystals varies with their distance from flow surfaces, becoming progressively larger toward flow interiors; crystals exceed 2 centimeters in diameter in the thickest ophitic flows on Isle Royale.

Porphyrite.-Rock with a porphyritic texture is produced by well-defined plagioclase crystals scattered through a finer grained groundmass. The term is applied to two distinct varieties of such porphyritic rocks. One variety has small, blocky, millimeter-sized plagioclase crystals, more or less uniformly distributed through the groundmass (fig. $4 B$ ); where the plagioclase crystals tend to clot together, the term "glomeroporphyrite" has been used (fig. $4 \mathrm{C}$ ). The other variety has larger, tabular crystals more randomly distributed and commonly occurring in clots (fig. $4 D$ ); the large crystals are often as long as $2 \mathrm{~cm}$.

Pegmatite.-Rock with a pegmatitic texture is that in which the minerals, especially the plagioclase, are unusually coarse when compared with the other volcanic rock types (fig. $4 E$ ). This term, as applied to Keweenawan lava flows, is of relatively recent usage (Cornwall, 1951a); Lane used the term "dolerite," one that is confusing because it is widely used in a different sense.

Trap.-Fine-grained massive rock called trap shows none of the distinctive textures indicated previously (fig. $4 F$ ). Lane tended to use "melaphyre" as a rock type and trap for a specific lava flow of that rock type, as for example, the Minong Trap. The term "trap" has also been used in the Michigan copper district to refer to the massive interior part of a flow, as distinguished from the amygdaloidal margins (amygdaloid). In this report "trap" will be used with a textural connotation and "is applied to any nonporphyritic aphanitic rock which is very dark gray or black, regardless of composition. It is thus equivalent to the term 'felsite' as used for lighter colored nonporphyritic aphanitic rocks" (Jackson, 1970, p. 300-301).

The main advantages of a textural classification over a compositional classification for rocks of the Portage Lake Volcanics arise not only from the ease of application in the field but from the nature of the volcanic rocks themselves. Individual flows within the volcanic sequence generally have a characteristic texture throughout; consequently certain stratigraphic units representing flows or groups of flows can be identified and traced in the field on the basis of their texture and thus are excellent stratigraphic marker units. These features are especially important in areas of limited outcrop, as on the west end of Isle Royale or in areas that have been structurally disturbed. On Isle Royale, 

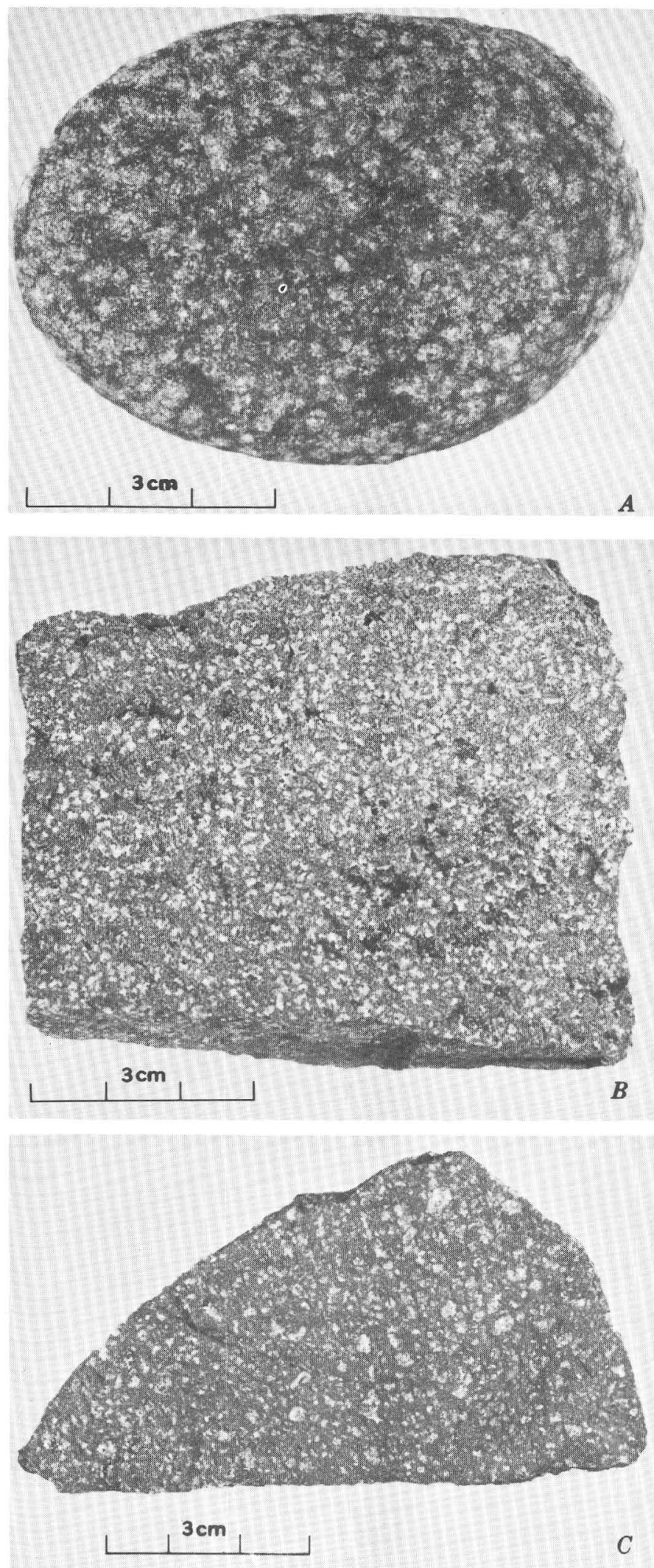

FIGURE 4.-Characteristic textures of volcanic rocks on Isle Royale. A, Typical ophite. Beach pebble from Mott Island. $B$, Fine-grained porphyrite. Scoville Point Flow from south side of North Government Island. $C$, Fine-grained porphyrite tending toward glomeroporphyrite. Tobin Harbor Flow from south side of Porter Island. $D$, Coarse porphyrite. Huginnin
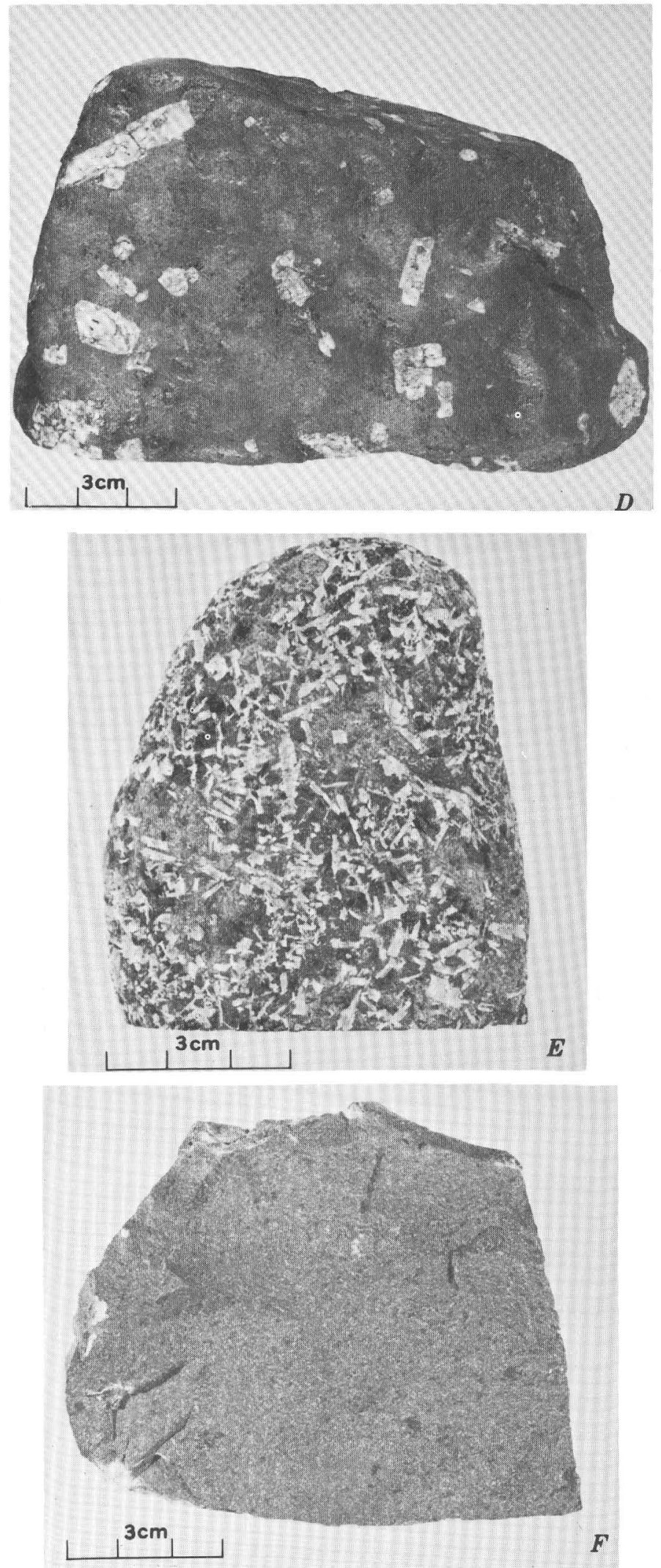

Flow from shoreline just west of Huginnin Cove. $E$, Pegmatite. From the differentiated zone of the Greenstone Flow on the east end of Passage Island. $F$, Trap. Minong Flow from the west end of Isle Royale. $A, B, D$, and $E$ show weathered surfaces. 


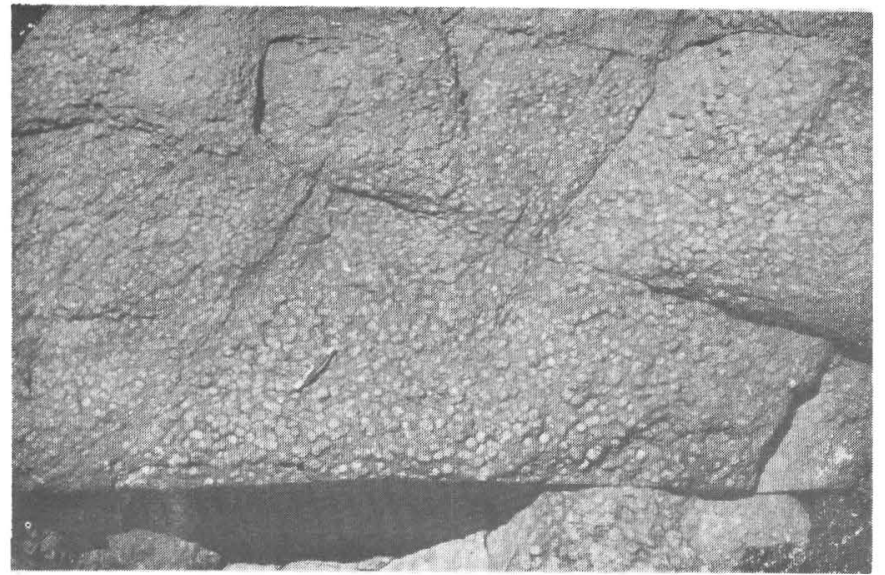

FIGURE 5.-Coarse ophite with knobby weathered surface. South side of Raspberry Island. Penknife, $7 \mathrm{~cm}$ long.

12 such flow units have been distinguished within the Portage Lake Volcanics, and these key units provide stratigraphic and structural control for geologic mapping on the island (fig. 6).

\section{COMPOSITION}

It has been long recognized that there is a general relation between the texture and the composition of the volcanic rocks in the Portage Lake Volcanics on the Keweenaw Peninsula, although there is considerable overlap. Butler and Burbank (1929) noted that ophitic texture is best developed in the more mafic lavas and that porphyritic and glomeroporphyritic textures are characteristic of more felsic flows or those approaching andesite. Cornwall (1951a) stated that "the ophites are predominantly basalts, whereas the porphyrites, glomeroporphyrites, and melaphyres are predominantly basaltic andesites."

The plagioclase in the ophites is generally labradorite; that in the porphyrites is labradorite or calcic andesine. The pyroxene is predominantly augite with small amounts of pigeonite in some ophitic flows. Ilmenite and magnetite are common accessory minerals. The major secondary minerals occurring both as alteration products and filling original voids include chlorite, sericite, prehnite, pumpellyite, chalcedony, laumontite, and calcite in addition to the opaque alteration products of the olivine.

Primary textures of the volcanic rocks on Isle Royale are well preserved; there is no development of schistosity. Nevertheless, the rocks have been pervasively altered, for of the original minerals, only the pyroxene remains generally fresh. The degree of alteration appears to be much greater on Isle Royale than in similar rocks on the Keweenaw Peninsula, where commonly plagioclase and occasionally olivine are fresh enough for their original compositions to be determined.

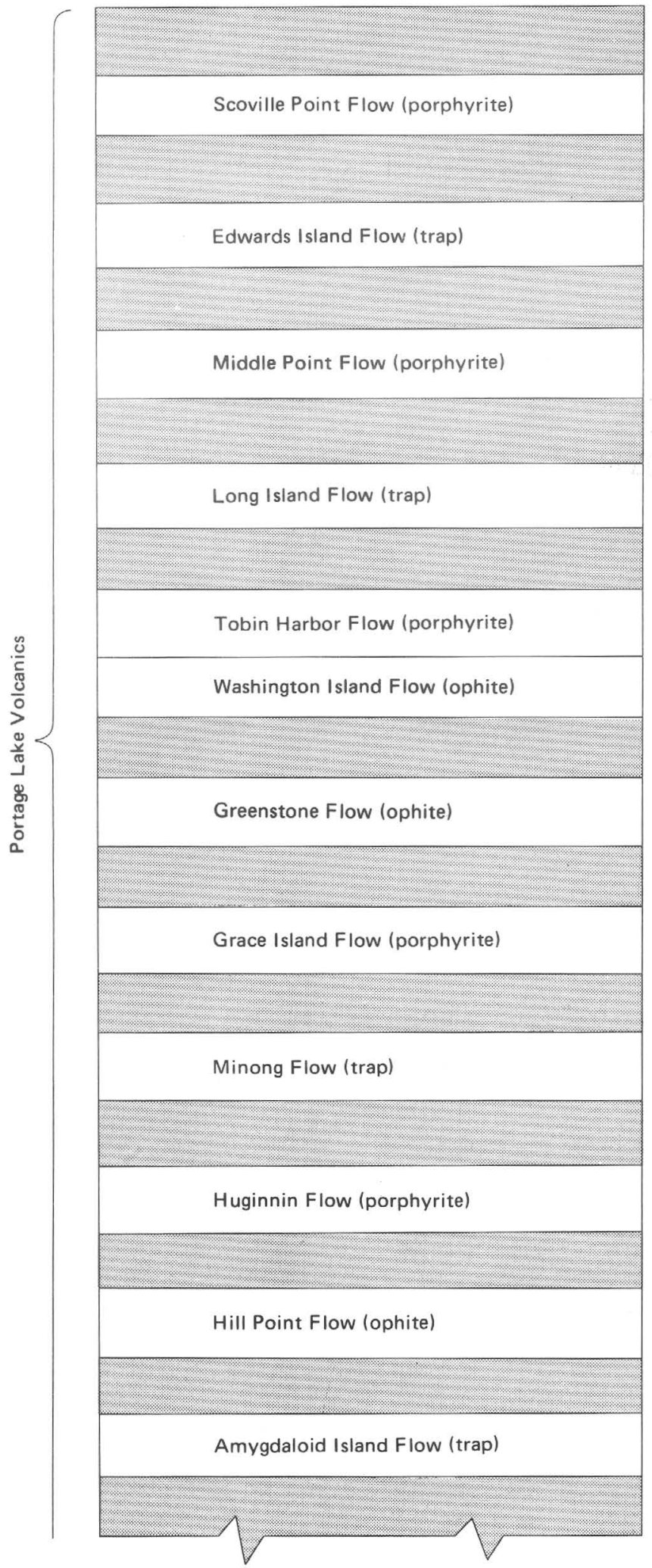

FIGURE 6.-Nomenclature for named volcanic flows within the Portage Lake Volcanics on Isle Royale. Shaded areas represent the undivided remainder of the sequence, consisting predominantly of ophitic volcanic rocks with lesser amounts of sedimentary and pyroclastic rocks. 
In the absence of quantitative mineralogical details from Isle Royale, chemical analyses of representative volcanic rocks are here used to characterize their composition (table 1). The extent to which alteration has affected the bulk chemistry of the rocks is unknown, but alteration is reflected to a certain extent by the presence of appreciable water, probably occurring chiefly in secondary minerals, and by the high oxidation state of the iron. To partially compensate for oxidation, the ferrous-ferric ratio was adjusted to $2: 1$ prior to calculating the normative minerals in table 1 .

According to the chemical classification of Irvine and Baragar (1971), which is based in part on normative mineralogy, the suite of rocks from Isle Royale is subalkaline, has tholeiitic affinities (fig. 7), and is predominantly basalt (fig. 8). The apparent variance of their classification with Cornwall's nomenclature results from his use of the classification system of Johannsen (1939), in which the dividing line between basalt and andesite is based solely on the modal anorthite content of the plagioclase (at 50 percent) and under which some of the basalts of this report would be called andesites.

\section{STRATIGRAPHIC UNITS}

The topography developed upon the rocks of the Portage Lake Volcanics on Isle Royale consists of a series of ridges and valleys alined in a northeast-southwest direction parallel to the regional strike of the formation (fig. 9). The southeast-facing slopes, controlled by the structural dip, are gentle compared with the northwest-facing antidip slopes and together provide a marked asymmetry to the ridge-and-valley cross profile. Because the sedimentary rocks in the series and the amygdaloidal zones at the base and top of flows are less resistant than the massive flow interiors, the interior parts of the thicker flows are the dominant ridgeforming units. The distinguishing texture of an individual flow is generally better developed and more readily apparent in the nonamygdaloidal or less-amygdaloidal flow interior. Fortunately, the part of a flow most useful for identification purposes is the part most likely to crop out. Contacts between flows, on the other hand, are seldom exposed, as they are generally concealed beneath alluvial materials or talus in the depressions between ridges.

Because the volcanic rocks on Isle Royale are predominantly ophitic, the nonophitic or the few unusually thick coarsely ophitic flows are most useful as stratigraphic markers. These include finer grained porphyrites and traps which, in addition to their unique textural identity, are generally more resistant to erosion than the ophites and tend to stand out topographically, adding to their usefulness in geologic mapping.

The 12 stratigraphic units within the Portage Lake Volcanics on Isle Royale that have been individually named include five porphyrites, four traps, and three ophites. All names are new except for the Huginnin and Minong Flows, formerly called Huginnin Porphyrite

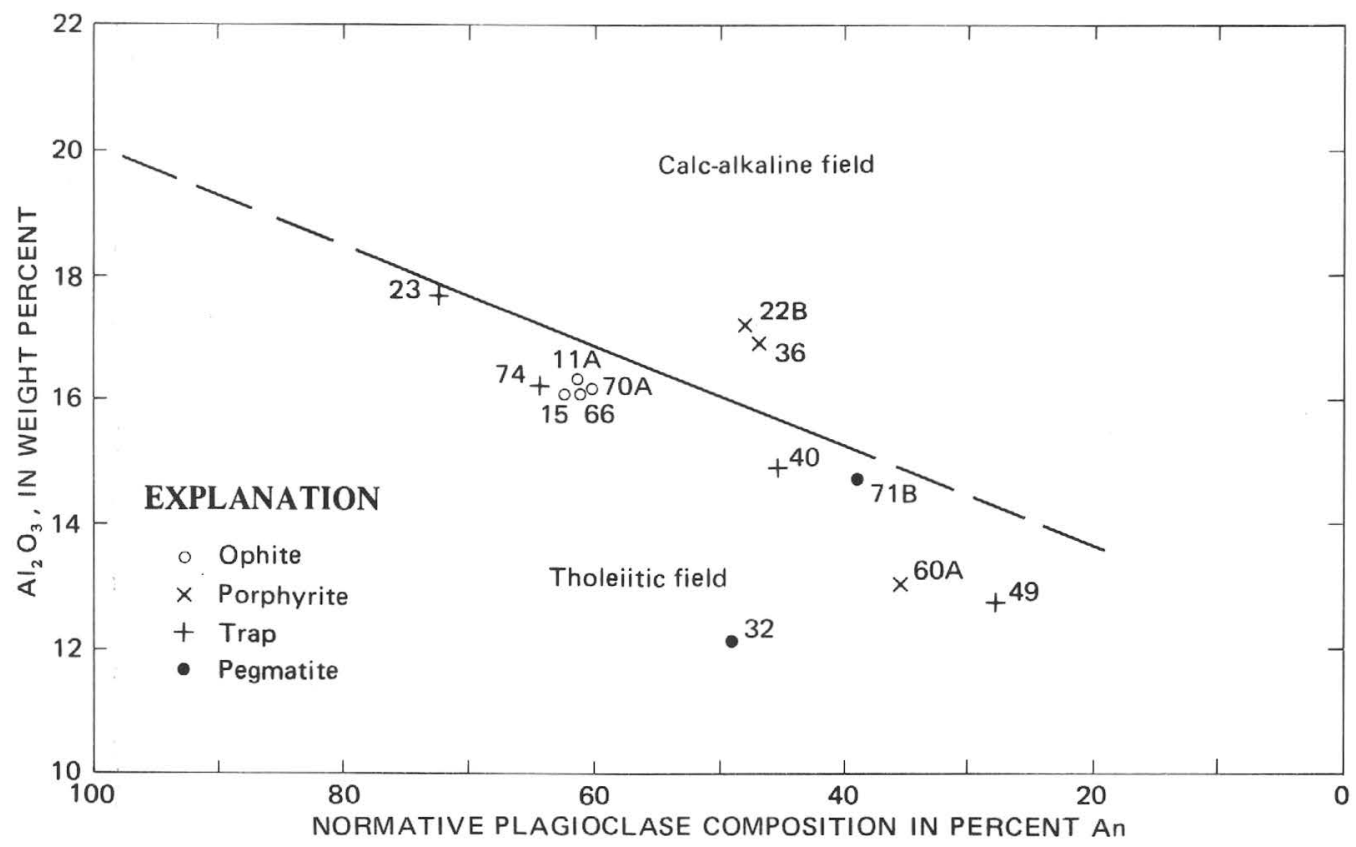

Figure 7.-Tholeiitic affinities of analyzed specimens of rocks from the Portage Lake Volcanics on Isle Royale. Classification used is that of Irvine and Baragar (1971). Numbers are keyed to analyses in table 1 . 
and Minong Trap, and the Greenstone Flow, originally named on the Keweenaw Peninsula. Six of these units can be traced the full length of the island, and two others about two-thirds the length.

The thickness of the units is difficult to estimate, in part because contacts are so sparsely exposed. Some thickness data can be obtained from Lane's (1898) descriptive log of a series of holes drilled across the island near its west end in 1891 and 1892, although correlation problems introduce some uncertainties. Several of the stratigraphic units used in this report appear to correlate with groups of flows in Lane's log rather than with individual flows. It is possible that Lane, in basing his conclusions on the presence of amygdaloidal rock in the core samples, overestimated the number of individual flow tops present or that there is duplication by faulting. Lane was aware of the problem, noting in numerous places in the log that the limits of some flows were very uncertain; in one place he noted that the samples from a core box had been mixed up. It is equally possible that some of the units reported here do indeed consist of multiple flows that are not individually discernible in the field. Each unit has its distinctive rock type, however, and must represent a single volcanic episode that produced rock differing in some respect from that immediately underlying or overlying the unit. The units thus are rock stratigraphic, and all may not necessarily be single flows.

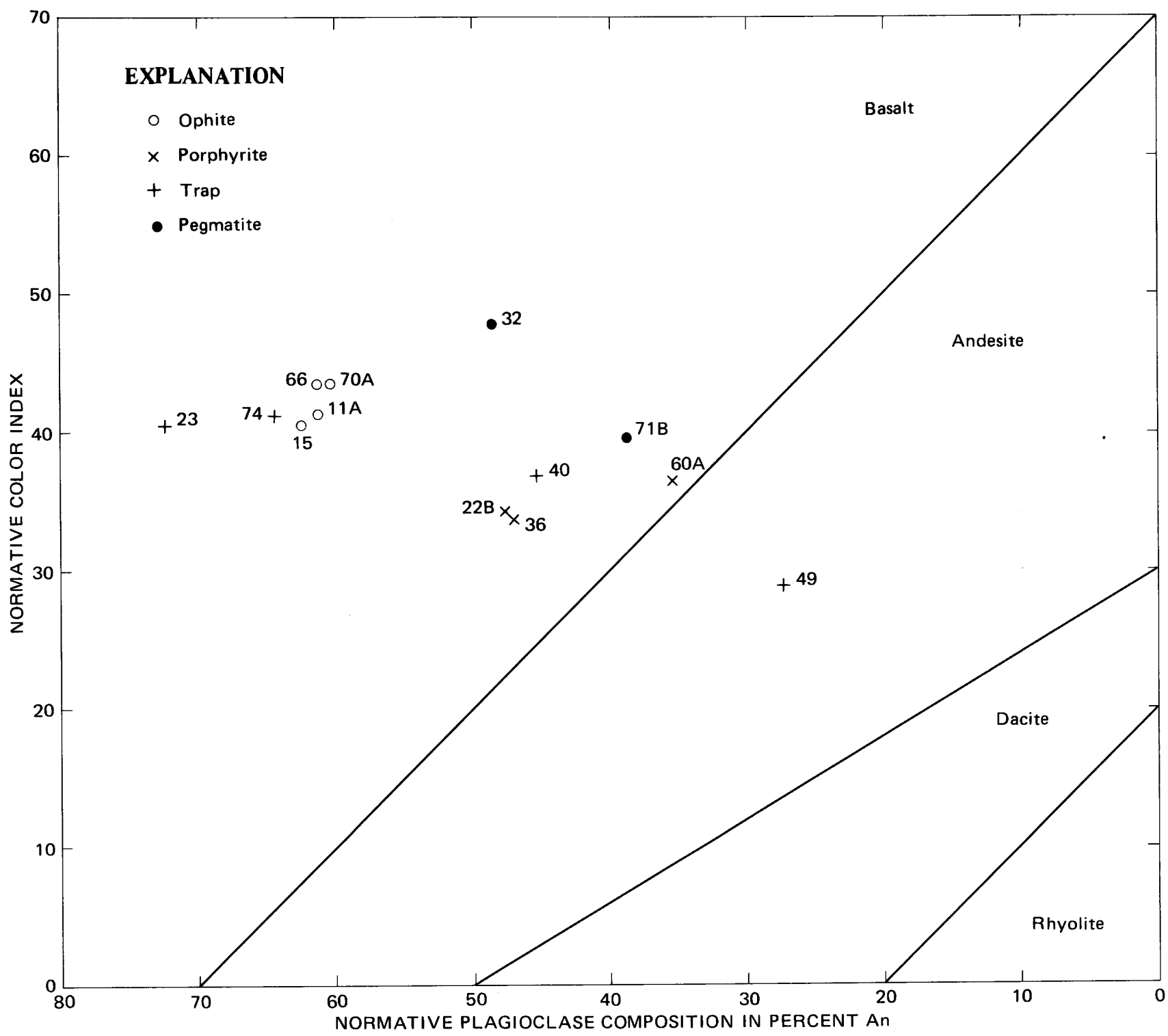

FIGURE 8.-Predominantly basaltic nature of analyzed specimens of rocks from the Portage Lake Volcanics on Isle Royale. Classification used is that of Irvine and Baragar (1971). Numbers are keyed to analyses in table 1. 
TABLE 1.-Analyses of volcanic rocks of

[Chemical analyses made by a single-solution procedure (Shapiro, 1967). Analysts: P. L. D. Elmore, Lowell Artis, S. D. Botts, Gillison Chloe, J. L. Glenn, series $1,0.7,0.5,0.3,0.2,0.15$, and 0.1 , which represent approximate midpoints of interval data on a geometric scale. The assigned interval for semiquan$\mathrm{Ag}, \mathrm{As}, \mathrm{Au}, \mathrm{Bi}$, Cd, Ge, Hf, Hg, In, Li, Mo, Pd, Pt, Re, Sb, Sn, Ta, Te, Th, Tl, U, W, Zn]

Rock type

Ophite

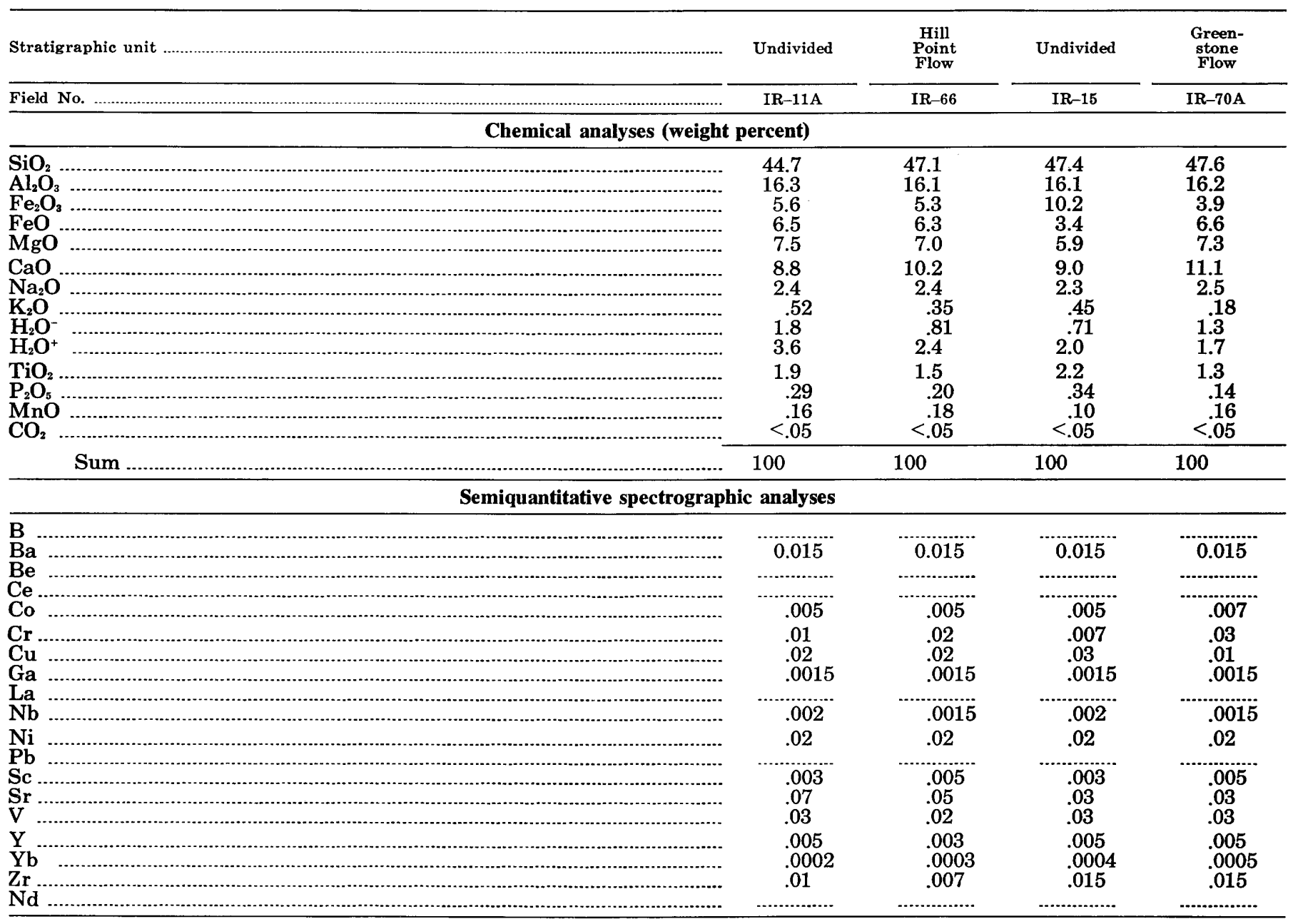

CIPW norms (weight percent)

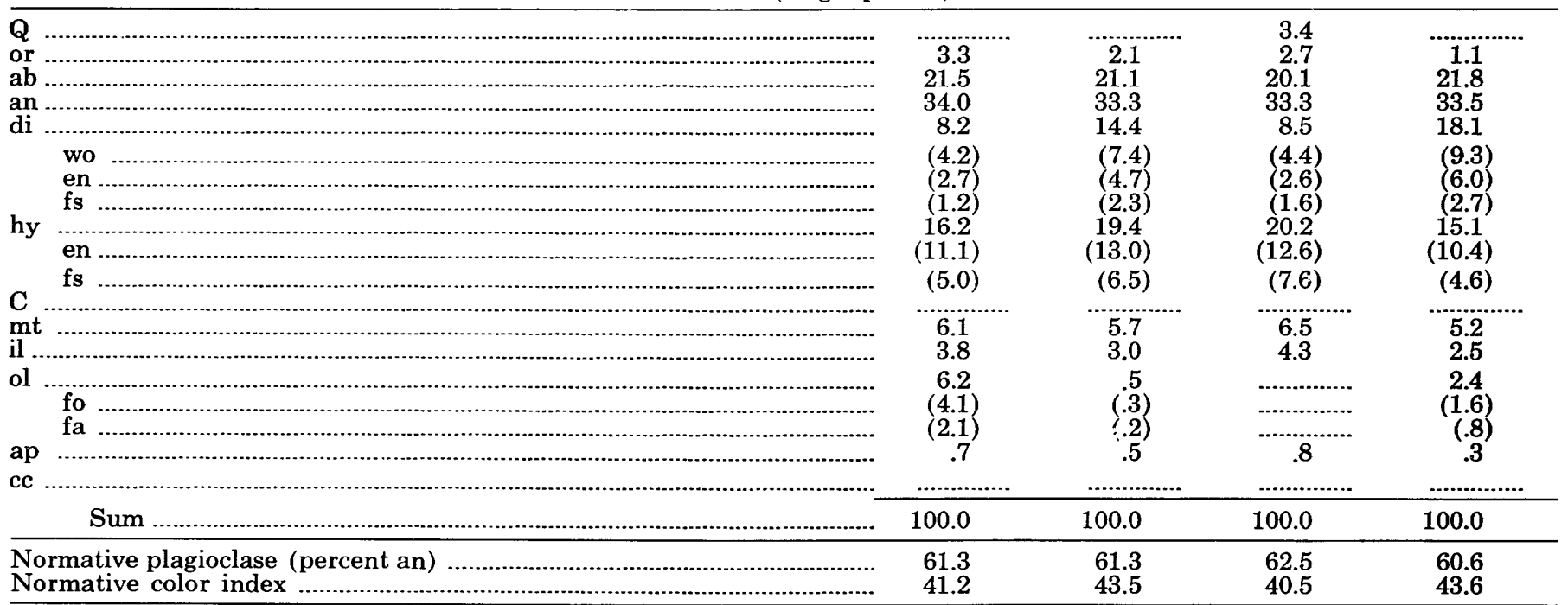

IR-11A. South shore of Raspberry Island.

IR-66. North side of Hill Point

IR-15. South shore of West Caribou Island.

IR-70A. North side of Blake Point near The Palisad's.
IR-23. North shore of Edwards Island.

IR-22B. South shore of Edwards Island.

IR-36. North shore of Tobin Harbor near Fire Island. 
the Portage Lake Volcanics, Isle Royale

James Kelsey, and Hezekiah Smith (rept. 68 WRC 26). Results of semiquantitative spectrographic analyses are reported to the nearest number in the titative results will include the quantitative value about 30 percent of the time. Analyst: Chris Heropoulos (rept. 68 MS 38 ). Looked for but not found:

\begin{tabular}{|c|c|c|c|c|c|c|c|c|}
\hline \multicolumn{2}{|c|}{$\underset{\text { trap }}{\text { Columnar }}$} & \multicolumn{2}{|c|}{$\begin{array}{l}\text { Fine-grained } \\
\text { porphyrite }\end{array}$} & \multirow{2}{*}{$\begin{array}{c}\begin{array}{c}\text { Coarse- } \\
\text { grained } \\
\text { porphyrite }\end{array} \\
\begin{array}{c}\text { Huginnin } \\
\text { Flow }\end{array}\end{array}$} & \multicolumn{2}{|c|}{ Trap } & \multicolumn{2}{|c|}{ Pegmatite } \\
\hline $\begin{array}{c}\text { Edwards } \\
\text { Island } \\
\text { Flow }\end{array}$ & $\begin{array}{l}\text { Green- } \\
\text { stone } \\
\text { Flow }\end{array}$ & $\begin{array}{c}\text { Scoville } \\
\text { Point } \\
\text { Flow }\end{array}$ & $\begin{array}{c}\text { Tobin } \\
\text { Harbor } \\
\text { Flow }\end{array}$ & & $\begin{array}{l}\text { Minong } \\
\text { Flow }\end{array}$ & $\begin{array}{l}\text { Amygda- } \\
\text { loid } \\
\text { Island } \\
\text { Flow }\end{array}$ & Undivided & $\begin{array}{l}\text { Green- } \\
\text { stone } \\
\text { Flow }\end{array}$ \\
\hline IR-23 & IR-74 & IR-22B & IR-36 & IR-60A & IR-40 & IR -49 & IR-32 & IR-71B \\
\hline \multicolumn{9}{|c|}{ Chemical analyses (weight percent)-Continued } \\
\hline 47.1 & 48.5 & 49.2 & 48.5 & 52.7 & 52.5 & 56.6 & 49.6 & 50.0 \\
\hline 17.7 & 16.2 & 17.2 & 16.9 & 13.0 & 14.9 & 12.7 & 12.1 & 14.7 \\
\hline 3.1 & 4.9 & 6.4 & 5.2 & 4.6 & 4.1 & 9.8 & 10.4 & 5.9 \\
\hline 5.2 & 5.4 & 4.2 & 6.2 & 8.2 & 7.4 & 3.5 & 3.4 & 5.4 \\
\hline 8.2 & 7.3 & 4.8 & 4.6 & 4.8 & 5.5 & 2.7 & 3.7 & 5.5 \\
\hline 10.9 & 9.8 & 9.5 & 8.4 & 5.5 & 7.2 & 3.0 & 12.3 & 8.1 \\
\hline 1.8 & 2.2 & 3.6 & 3.6 & 3.8 & 3.2 & 3.2 & 2.6 & 3.7 \\
\hline .13 & .14 & .96 & 1.3 & .28 & 1.3 & 2.9 & .12 & 1.2 \\
\hline 2.2 & 2.2 & .34 & .54 & .91 & .45 & .74 & .06 & .53 \\
\hline 1.9 & 1.6 & 1.9 & 2.3 & 3.2 & 1.8 & 1.9 & 1.7 & 2.5 \\
\hline .93 & 1.4 & 1.5 & 2.1 & 2.3 & 1.7 & 2.0 & 3.3 & 2.1 \\
\hline .08 & .15 & .16 & .26 & .39 & .29 & .71 & .43 & .20 \\
\hline .15 & .16 & .16 & .16 & .15 & .15 & .18 & .18 & .13 \\
\hline .31 & $<.05$ & .08 & $<.05$ & $<.05$ & $<.05$ & $<.05$ & $<.05$ & $<.05$ \\
\hline 100 & 100 & 100 & 100 & 100 & 100 & 100 & 100 & 100 \\
\hline \multicolumn{9}{|c|}{ Semiquantitative spectrographic analyses-Continued } \\
\hline & & 0.003 & 0.001 & 0.001 & & 0.001 & 0.002 & 0.002 \\
\hline 0.005 & 0.01 & .02 & .03 & .015 & 0.03 & .07 & .002 & .05 \\
\hline 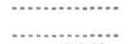 & 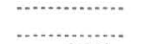 & (n) & (n) & .01 & (n) & .015 & (n) & ....... \\
\hline .005 & .005 & .005 & .005 & .005 & .005 & .003 & .003 & .005 \\
\hline .03 & .02 & .02 & .015 & .003 & .01 & & .007 & .02 \\
\hline .01 & .015 & .007 & .007 & .03 & .02 & .02 & .07 & .015 \\
\hline .001 & .0015 & .0015 & .0015 & .0015 & .0015 & .002 & .0015 & .0015 \\
\hline (n)................ & ............ & ….......... & .......... & .007 & .005 & .01 & .003 & ............. \\
\hline .03 & .03 & $\begin{array}{l}.0015 \\
.007\end{array}$ & $\begin{array}{l}.0015 \\
.007\end{array}$ & .003 & .015 & $\begin{array}{l}.005 \\
.0003\end{array}$ & .002 & .002 \\
\hline & & & .003 & .001 & .001 & .001 & & \\
\hline .005 & .003 & .005 & .005 & .005 & .003 & .003 & .005 & .005 \\
\hline .03 & .05 & .05 & .07 & .015 & .05 & .015 & .05 & .05 \\
\hline .02 & .02 & .03 & .03 & .03 & .02 & .007 & .05 & .05 \\
\hline .002 & .005 & .003 & .007 & .007 & .005 & .01 & .007 & .007 \\
\hline .0002 & .0005 & .0003 & .0005 & .0007 & .0007 & .001 & .0007 & .0007 \\
\hline .005 & .01 & .01 & .02 & .02 & .02 & .05 & .02 & .015 \\
\hline 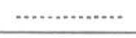 & ................... & ..................... & ...................... & ................. & ..................... & .01 & ..................... & ...................... \\
\hline \multicolumn{9}{|c|}{ CIPW norms (weight percent)_Continued } \\
\hline 1.2 & 3.3 & & & 9.7 & 4.8 & 14.8 & 8.2 & \\
\hline .8 & .9 & 5.8 & 7.9 & 1.7 & 7.8 & 17.7 & .7 & 7.3 \\
\hline 15.9 & 19.4 & 31.3 & 31.4 & 33.6 & 27.6 & 28.0 & 22.6 & 32.4 \\
\hline 41.7 & 35.3 & 28.7 & 26.9 & 18.4 & 22.9 & 10.6 & 21.6 & 20.6 \\
\hline 9.9 & 11.5 & 14.8 & 11.7 & 6.1 & 9.4 & ................ & 31.3 & 15.9 \\
\hline$(5.1)$ & $(6.0)$ & $(7.6)$ & $(6.0)$ & (3.1) & $(4.8)$ & ................. & (15.9) & $(8.2)$ \\
\hline$(3.6)$ & $(3.9)$ & (4.4) & $(3.4)$ & (1.7) & $(2.9)$ & ................. & (8.5) & $(5.0)$ \\
\hline (1.2) & (1.6) & $(2.8)$ & $(2.3)$ & (1.3) & (1.7) & & $(6.9)$ & $(2.7)$ \\
\hline 23.5 & 21.3 & 5.7 & 6.4 & $\begin{array}{l}18.5 \\
(108)\end{array}$ & 17.9 & 16.4 & $\begin{array}{l}1.6 \\
(.9)\end{array}$ & $\begin{array}{l}12.7 \\
(8.3)\end{array}$ \\
\hline $\begin{array}{r}(17.8) \\
(5.7)\end{array}$ & $\begin{array}{r}(15.0) \\
(6.3)\end{array}$ & $\begin{array}{l}(3.5) \\
(2.2)\end{array}$ & $\begin{array}{l}(3.9) \\
(2.5)\end{array}$ & $\begin{array}{r}(10.8) \\
(7.7)\end{array}$ & $\begin{array}{r}(11.1) \\
(6.8)\end{array}$ & $\begin{array}{l}(7.0) \\
(9.4)\end{array}$ & $\begin{array}{l}(.9) \\
(.7)\end{array}$ & $\begin{array}{l}(8.3) \\
(4.4)\end{array}$ \\
\hline$(0.7)$ & $(0.3)$ & $(2.2)$ & $(2.0)$ & $(1.0)$ & (............ & .6 & (.......... & \\
\hline 4.2 & 5.1 & 5.1 & 5.6 & 6.4 & 5.6 & 6.4 & 6.5 & 5.5 \\
\hline 1.8 & 2.8 & 2.9 & 4.1 & 4.6 & 3.3 & 3.9 & 6.4 & 4.1 \\
\hline ................ & ……........ & 5.2 & 5.4 & ................ & .................. & ................ & ................... & .9 \\
\hline .................. & ................... & (3.1) & $(3.2)$ & ................... & .................. & ................... & ........... & (.6) \\
\hline & ......... & $(2.2)$ & (2.3) & & & & & (.3) \\
\hline .2 & .4 & .4 & .6 & 1.0 & .7 & 1.7 & 1.0 & .5 \\
\hline .7 & ............... & .2 & ..................... & .................... & .................... & ............. & ……............ & ..................... \\
\hline 100.0 & 100.0 & 100.0 & 100.0 & 100.0 & 100.0 & 100.0 & 100.0 & 100.0 \\
\hline 72.5 & 64.5 & 47.9 & 47.0 & 35.4 & 45.4 & 27.5 & 48.9 & 38.9 \\
\hline 40.4 & 41.1 & 34.2 & 33.8 & 36.6 & 36.9 & 28.9 & 47.9 & 39.7 \\
\hline
\end{tabular}

IR-60A. Small point on west side of Lane Cove.
IR-40. East end of most northwesterly point on main island,

IR-49. South shore at east end of Amygdaloid Island. 


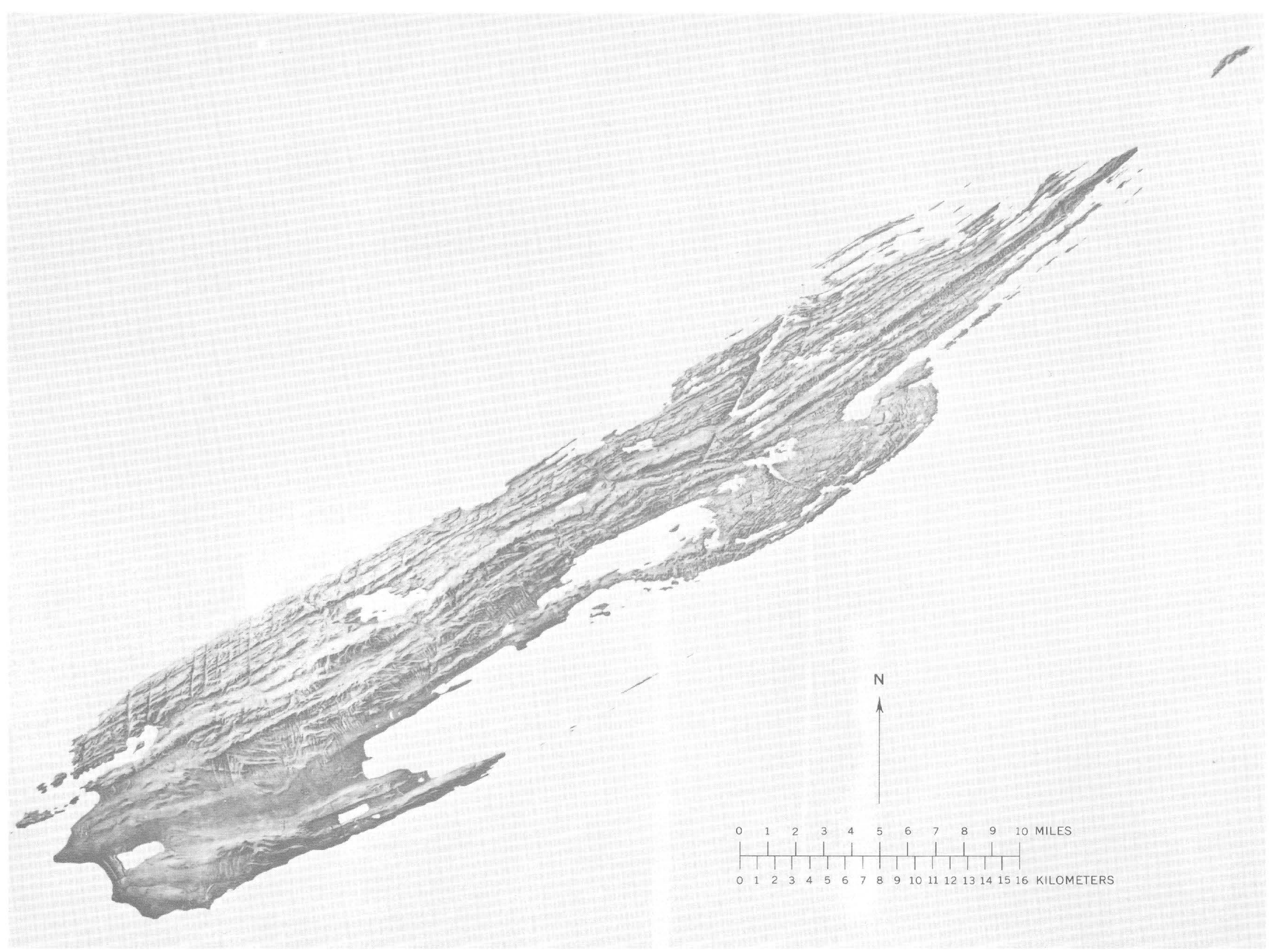

FTGURE 9.-Shaded relief map of Isle Royale National Park Prepared by Alexius J. Burgess (U.S. Geol. Survey, 1957). 
In the discussion that follows, the stratigraphic units are grouped by rock type and not in any specific stratigraphic sequence. In order to provide a stratigraphic framework within which to view the individual units, the sequence is shown in a schematic columnar section (fig. 10). The distribution of some of the units is shown on the bedrock map (fig. 11).

\section{PORPHYRITE FLOWS}

Scoville Point, Middle Point, and Tobin Harbor Flows

The rock in the Scoville Point, Middle Point, and Tobin Harbor Flows is similar and somewhat unusual; it is not known to crop out elsewhere in the stratigraphic section on Isle Royale. Lane $(1898$, p. 170), recognizing their distinctive character, informally referred to them together as "the Tobin porphyrites" for occurrences in the Tobin Harbor area.

The Scoville Point Flow is well exposed on the end of Scoville Point, its type locality, at the east end of Rock Harbor. It also is exposed on Edwards and North Government Islands, along part of the north shore of Rock Harbor, along the north shore of Lake Richie, and at scattered localities over the length of the island. On the western part of the island, Red Oak Ridge, which there rivals Greenstone Ridge in height, is preserved because it is capped and armored by the resistant Scoville Point Flow. The rock characteristically has fine equant millimeter-sized plagioclase crystals distributed uniformly througin a fine-grained matrix; the texture can best be seen on weathered surfaces (fig. $4 B$ ). The unit is at least 100 feet thick at Scoville Point and locally may be as much as 200 feet thick.

The Middle Point Flow is nowhere well exposed. The most accessible outcrop is a small one, considered its type locality, on the south shore of Grace Harbor about half a mile northeast of Middle Point. The flow can be traced northeastward through scattered outcrops for a distance of 12 miles; it appears to be absent for about 9 miles further along strike, and then is exposed over an extent of 2 miles north of Siskiwit Lake. It may not occur on the eastern third of the island. The texture of the Middle Point Flow is similar to that of the Scoville Point Flow except that the plagioclase crystals are less uniform in size and distribution and have a tendency to clot together as in a glomeroporphyrite (fig. $4 \mathrm{C}$ ). The thickness of the flow is probably somewhat more than 50 feet.

The Tobin Harbor Flow is well exposed on the south arm of Porter Island, along the north side of Tobin Harbor, its type locality, and westward through scattered outcrops for the length of the island. Good outcrops occur on the Mount Franklin Trail just north of Tobin Creek. North of Siskiwit Lake and south of Lake
Desor, the Tobin Harbor Flow makes up much of the south slope of Greenstone Ridge. The rock is identical in appearance with the Middle Point Flow, tending toward a glomeroporphyrite (fig. $4 C$ ). The flow is probably at least 50 feet thick in the Tobin Harbor area and may be somewhat more than 100 feet thick in the central part of the island.

\section{Huginnin and Grace Island Flows}

The rock of the Huginnin and Grace Island Flows is the most distinctive volcanic rock on the island, with its large euhedral tabular plagioclase crystals floating randomly in a fine-grained groundmass (fig. 12). Even as beach pebbles or cobbles, this rock is easily recognized (fig. 13). In referring to the Huginnin Flow, Lane $(1898$, p. 89) stated that there was no other flow like it in the whole series; except for the Grace Island Flow, which he apparently overlooked, this appears to be true.

The Huginnin Flow was originally named the Huginnin Porphyrite by Lane for outcrops that occur in the bed of Huginnin Creek just a short distance from where the creek flows into Huginnin Cove near the northwest corner of the island. Although the outcrops in the creek are rather poor, excellent wave-washed outcrops occur on the shoreline about a quarter of a mile southwest of Huginnin Cove. At that locality, the upper contact of the flow is exposed and the plagioclase phenocrysts can be seen to extend undiminished in abundance and size through the amygdaloidal zone to the top of the flow. On the western third of the island, the Huginnin Flow occurs beneath a rather thick cliffforming ophitic flow and as a consequence is generally buried under talus. However, it can be traced by scattered outcrops from just west of Huginnin Cove to Little Todd Harbor. From Todd Harbor eastward it can be traced for the length of the island, the most accessible outcrops being at the east end of Todd Harbor, at the mouth of McCargoe Cove, and on a small peninsula on the west side of Lane Cove. Lane's drill log gives a thickness of 67 feet for the Huginnin Porphyrite at the northwest corner of the island.

The rock of the Grace Island Flow is indistinguishable from that of the Huginnin Flow. The best and most easily accessible exposures occur on the offshore islands at the west end of Isle Royale proper; on a point south of the campground on Grace Island, its type locality, on Booth Island, and on both ends of Washington Island. On the west end of Washington Island, the base of the flow is exposed, and the plagioclase phenocrysts can be seen to extend through the basal amygdaloidal zone to the bottom of the flow. Outcrops of the Grace Island Flow are not only poor but scarce on the main island, and the unit can be traced by means of very scattered outcrops for about 6 miles eastward from 


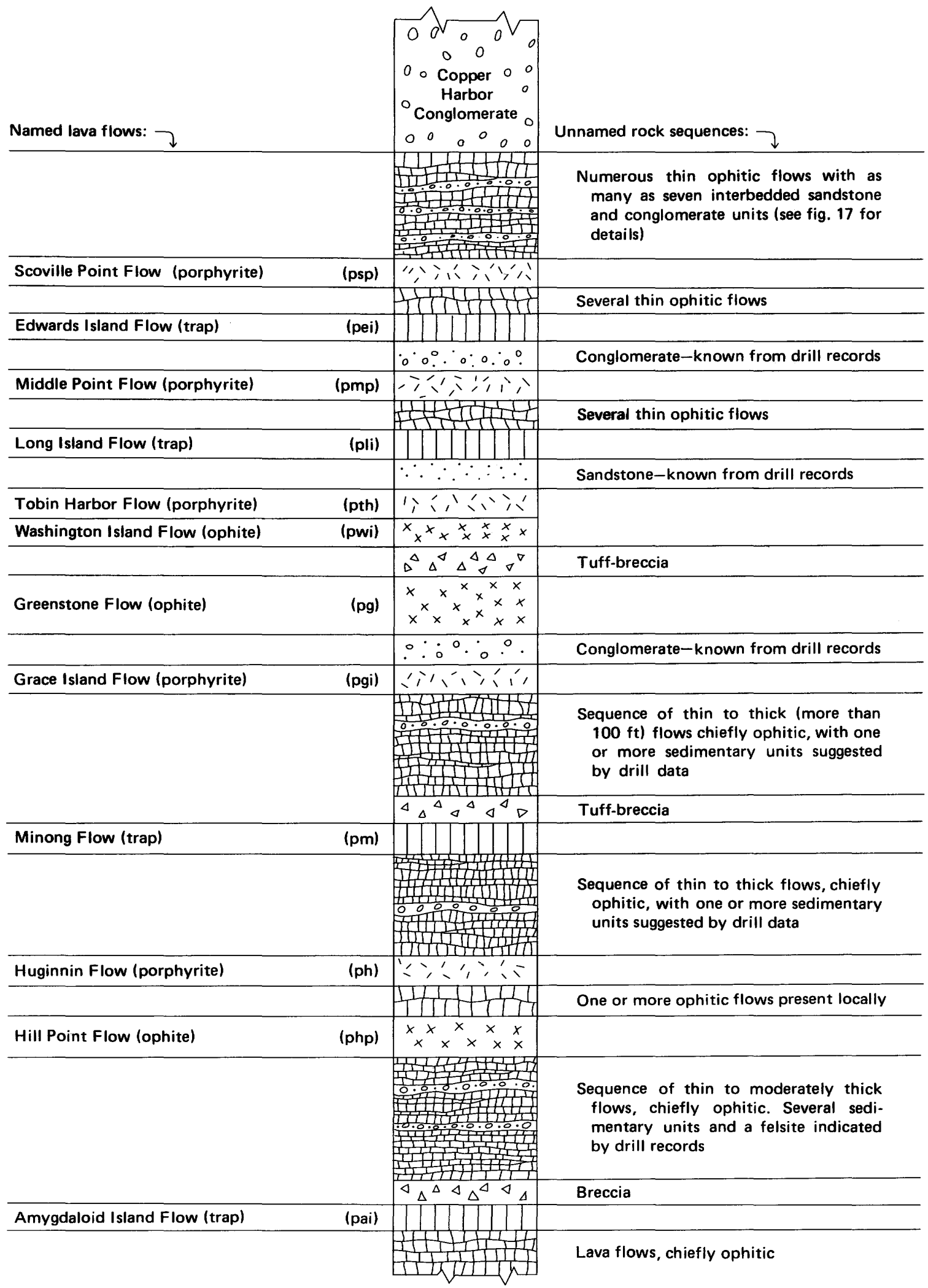

FIgURE 10.-Schematic columnar section of the Portage Lake Volcanics on Isle Royale. Not drawn to scale. 
Grace Harbor. That the unit is more extensive is suggested by a single recognized occurrence of the distinctive porphyrite in the same stratigraphic position just beneath the Greenstone Flow on Greenstone Ridge in the central part of the island just north of the Greenstone Ridge Trail about 1 mile east of the east end of Hatchet Lake. On Washington Island and for some distance eastward, the Greenstone Flow is relatively thin, but at about the point where the Grace Island Flow becomes difficult to trace, the Greenstone Flow thickens eastward and becomes more and more a cliff former, burying its own base, as well as the immediately underlying section, beneath massive piles of talus. The Grace Island Flow is probably about 50 feet thick on Washington Island; elsewhere its thickness is unknown.

\section{TRAP FLOWS}

\section{EdWards IsLaNd and Long Island Flows}

The Edwards Island and Long Island Flows, chemically the most basaltic of the rocks analyzed (fig. 8), have important secondary attributes that help in field recognition. With the exception of the upper "chill" zone of the Greenstone Flow, they are the only flows in the stratgraphic section to exhibit well-developed columnar jointing. Lane noted what he referred to as "basaltic" jointing and conchoidal fracture and referred to the rock as "columnar trap." Where the columnar jointing is not well developed, the rock usually exhibits polygonal rather than rectangular jointing, and this, together with fine grain size and conchoidal fracture, aids in field identification.

The type locality for the Edwards Island Flow is the good exposure on the north side of Edwards Island. It is also exposed on adjacent islands and on the point just north of Scoville Point on the south side of Tobin Harbor; columnar jointing is also well developed at these localities (fig. 14). From the Tobin Harbor area, the unit can be traced westward through scattered outcrops for nearly 30 miles to just northwest of Hay Bay. West of Hay Bay the amount of surficial cover on the island increases markedly, and although the Edwards Island Flow may continue farther west, it is concealed. Other accessible areas where the columnar jointing can be observed are the place where the trail from Rock Harbor to Mount Franklin crosses the flow and the south slope of Ransom Hill just west of the trail from Daisy Farm Campground to Mount Ojibway. In thickness the Edwards Island Flow probably averages about 50 feet.

The Long Island Flow is exposed on a chain of small narrow islands in Tobin Harbor, including Long Island, its type locality. Columnar jointing is not noticeable in the Tobin Harbor area, but polygonal jointing is well developed on Long and Third Islands. Although the Long Island Flow can be traced as far west as the Edwards Island Flow, to just northwest of Hay Bay, outcrops are generally very poor, and at only one relatively inaccessible locality was well-developed columnar jointing observed. About 11/4 miles west of Lake Richie along the north fork of the creek draining into the west end of the lake, columns form a cliff about 25 feet high. The Long Island Flow commonly contains sparse small bluish agate amygdules that help distinguish isolated outcrops of this unit from those of the Edwards Island Flow, in which agates have not been observed. Because the islands where the flow is best exposed project only a few feet above water level, a stratigraphic thickness of no more than 25 feet is visible; however, the flow is probably less than 50 feet thick.

\section{Minong Flow}

The Minong Flow was originally named the "Minong Trap" by Lane $(1898$, p. 16) for its occurrence at the Minong mine. The rock is dark and fine grained and has a pronounced conchoidal fracture (fig. $4 F$ ). Lane noted a tendency toward "basaltic" (columnar) jointing, but no well-developed columns were observed in the present study. Because it is thick and resistant, the Minong Flow is an excellent ridge former and can easily be traced the length of the island. In fact, Minong Ridge is generally characterized by the precipitous antidip slopes on its north side. The rock is further characterized by the presence of sparse bluish-white agate amygdules. The Minong Ridge Fire Manway (trail) follows the Minong Flow for much of its length and thus makes numerous outcrops of the flow readily accessible. Excellent wave-washed outcrops are found on some of the small promontories jutting into Lake Superior, especially north of Locke Point, in Five Finger Bay, and at the far west end of Isle Royale. At the west-end locality, the base of the unit is exposed and the rock is uniformly dense down to the contact, with almost no amygdaloidal zone present. The thickness of the Minong Flow is 77 feet in Lane's drill log.

Lane $(1898$, p. 82$)$ also described and named a "Minong Porphyrite," which he designated more felsic than the rock he described as "Tobin porphyrite" and which occurs immediately above his "Minong Trap." In fact, he considered the porphyrite and trap possibly to be magmatic differentiates of a single flow. In describing the porphyrite from drill samples, Lane noted "the extreme fineness of grain, the scoriaceous, porous and brecciated appearance, peculiar in that the pores are fine and irregular." Lane's Minong Porphy- 


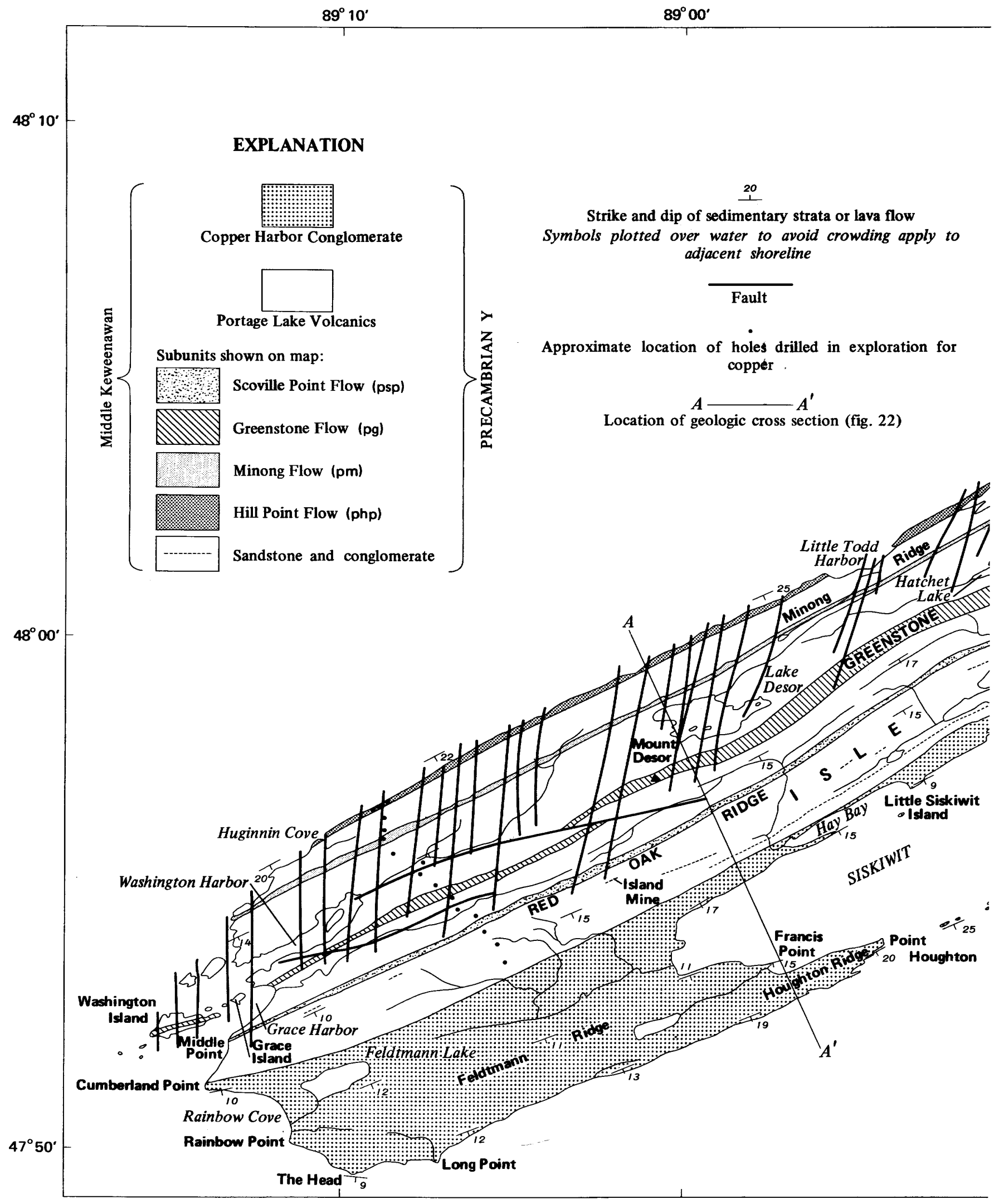

FigURE 11.-Simplified bedrock geology of Isle Royale. Scale too small to show all stratigraphic units described 


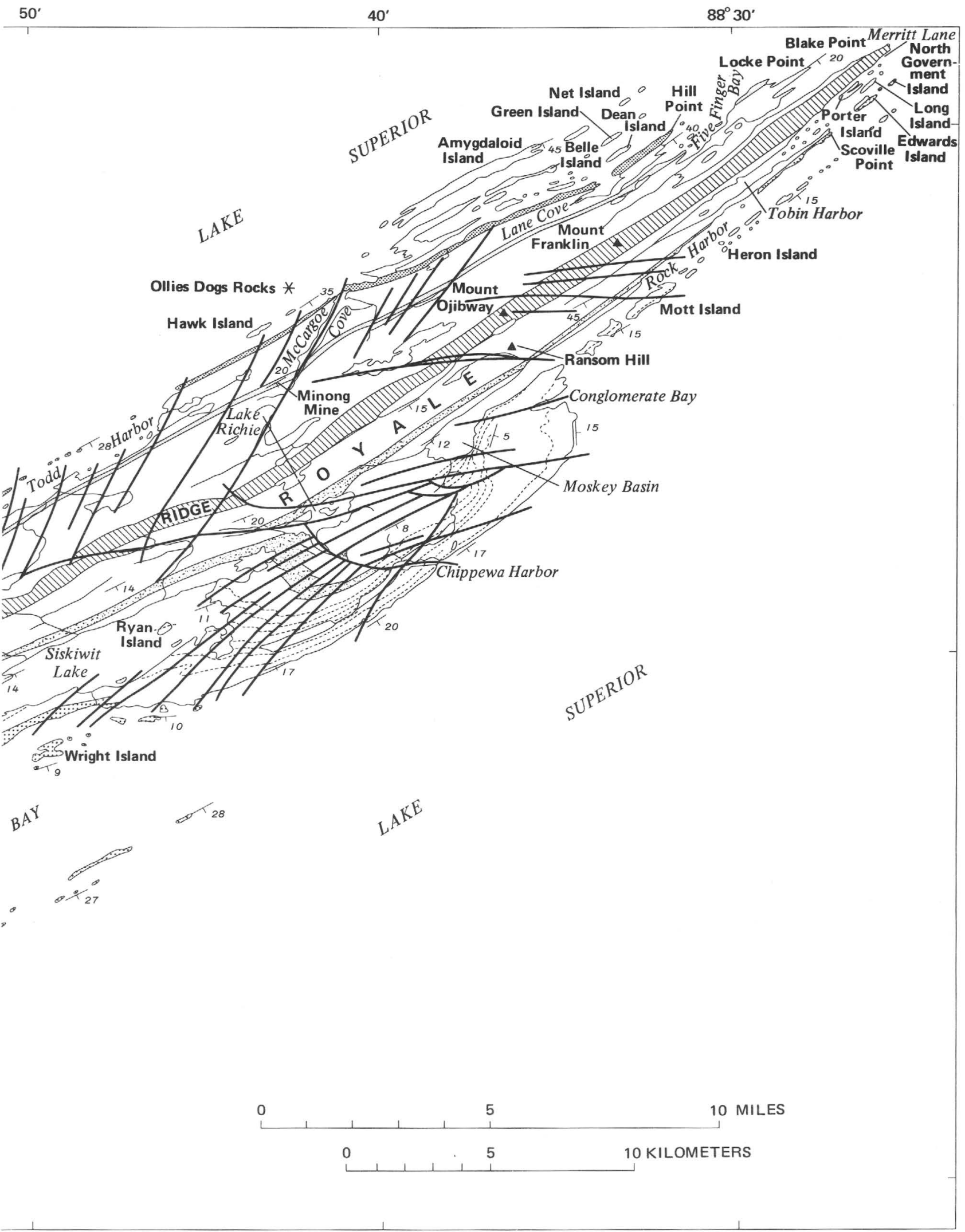

in text. For additional details, see larger scale geologic map $(1: 62,500)$ published separately (Huber, $1973 b)$. 




Figure 12.-Porphyrite from Huginnin Flow. Loose slab on beach at Huginnin Cove. Pencil, approximately $15 \mathrm{~cm}$ long.

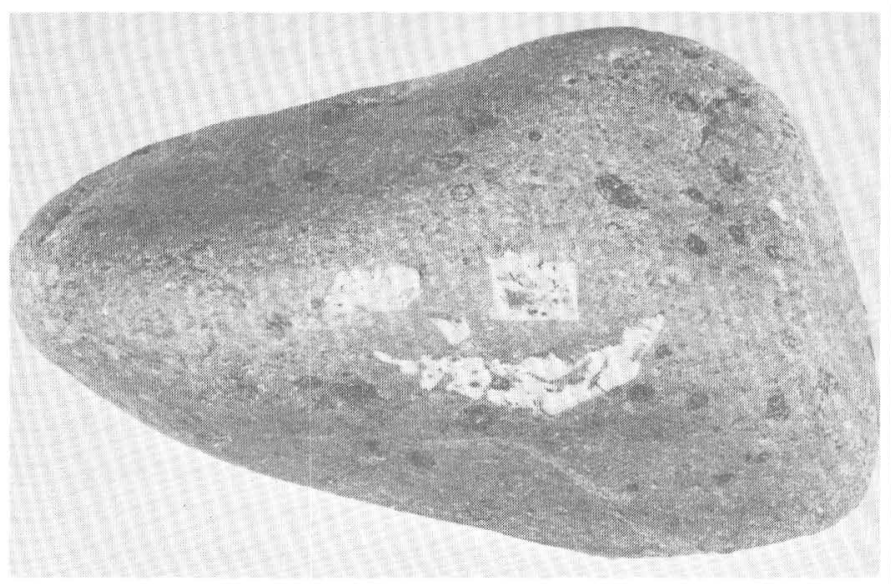

FIGURE 13.-Beach cobble of porphyrite from Grace Island Flow with a rather unusual distribution of plagioclase phenocrysts. Dark spots are amygdules of pumpellyite. From beach on Grace Island; long dimension, $15 \mathrm{~cm}$.

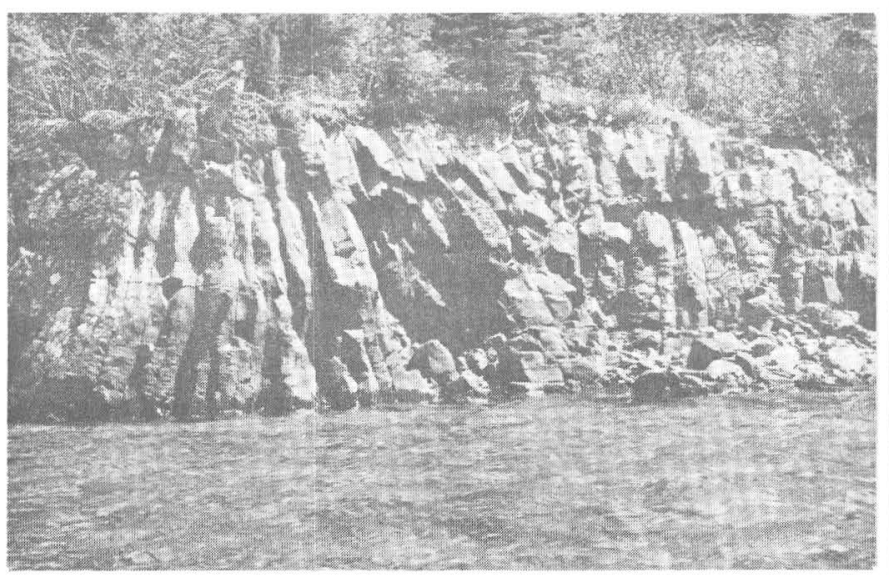

FIgURE 14.-Columnar jointing in Edwards Island Flow on north side of Edwards Island. rite, now believed to be of pyroclastic origin, is discussed in a later section.

\section{AMYGDALOID ISLAND FLOW}

The Amygdaloid Island Flow, an andesite, is the most felsic volcanic rock of those analyzed (fig. 8; table 1). It is exposed only on Amygdaloid Island near the base of the exposed stratigraphic section of the Portage Lake Volcanics. Like the other traps, it is a resistant rock and forms the highest ridge running the length of Amygdaloid Island. Some of the best and most accessible exposures are those on the promontory south of Crystal Cove at the east end of the island, its type locality, and at the natural bridge in the central part of the island-a wave-cut arch formed at a time when a higher lake level existed in the Superior basin (Huber, 1973a). One of the most distinctive aspects of the rock is the presence of rather abundant agates with a characteristic flesh-pink cast and commonly with centers of massive or drusy quartz (fig. 15). The Amygdaloid Island Flow is probably less than 50 feet thick.

\section{OPHITE FLOWS}

The volcanic rocks in the Portage Lake Volcanics on Isle Royale are predominantly ophitic. The stratigraphic marker units described to this point are nonophitic and thus are useful because of their conspicuous



FIGURE 15.-Specimen of Amygdaloid Island Flow with characteristic agate amygdules (sawed surface). From northeast end of Amygdaloid Island. 
contrast within the generally ophitic sequence. Three ophitic flows on Isle Royale, however, are useful marker horizons because they also stand out from the mass of ophitic flows: the Greenstone, Hill Point, and Washington Island Flows.

\section{GreEnStone Flow}

Lane (1898, p. 98) referred to the Greenstone Flow as "the Greenstone, the 'backbone' [of the island] and biggest ophite of all." Application of this formal name to the flow on Isle Royale resulted from Lane's correlation of this flow with the type Greenstone of the Keweenaw Peninsula, the thickest ophitic flow there. The name "Greenstone" eventually evolved into "Greenstone Flow" on the peninsula, and as the correlation with Isle Royale is still considered valid, the name Greenstone Flow is also used on the island. The Greenstone Flow on Isle Royale, as on the peninsula, has undergone magmatic differentiation, and this feature primarily, in addition to thickness, led to the correlation. Extensive descriptions and analytical data for the Greenstone Flow on the Keweenaw Peninsula were presented by Broderick (1935) and Cornwall (1951a, b).

As late as 1911, some workers considered the "Greenstone," both on the Keweenaw Peninsula and on Isle Royale, to be an intrusive sill because of its thickness and differentiated character (Van Hise and Leith, 1911, p. 381, 389). Lane (1911, p. 939-940), however, argued convincingly for its origin as a lava flow, an interpretation confirmed by subsequent work on the peninsula based on thousands of feet of diamond-drill samples (for example, Broderick and others, 1946, p. 683-684).

The Greenstone Flow is indeed the backbone of Isle Royale, for it forms the most prominent ridge running the length of the island, Greenstone Ridge. The Greenstone Ridge Trail, which follows the ridge for nearly its entire length, provides access to numerous scattered outcrops, but only at the far east end of the island near Blake Point is a reasonably complete cross section of the flow exposed. There the flow can be seen to consist of four units with the following approximate thicknesses: A lower ophitic zone (100 ft), a central pegmatitic zone (75 ft), an upper ophitic zone $(175 \mathrm{ft})$, and an uppermost columnar-jointed trap (50 ft), for a total thickness of about 400 feet. The Greenstone Flow is thickest in the cental part of Isle Royale, where it is estimated to be nearly 800 feet thick. It thins westward to less than 100 feet on Washington Island.

The lower ophitic zone, which makes up the cliffs of The Palisades near Blake Point at the east end of the island, shows an increase in grain size of the ophitic augite crystals from a few millimeters near the base (base not exposed) to as much as $1 \frac{1}{2} \mathrm{~cm}$ in the upper part of the zone. The contact between the lower ophitic zone and the pegmatitic zone is not exposed but is considered to be fairly abrupt, as it can be projected with good continuity between outcrops of the two rock types for a distance of more than 30 miles and at places can be located within a stratigraphic interval of 25 feet. The pegmatitic zone is extremely variable in texture and grain size but characteristically has an interlocking mat of elongate plagioclase crystals, which are as much as $2 \mathrm{~cm}$ long (fig. $4 E$ ). The contact of the pegmatitic zone with the upper ophitic zone is gradational over a few tens of feet, with irregular patches of the two rock types intermingling. The upper ophitic zone is fairly coarse at its base, with augite crystals as much as $1 \mathrm{~cm}$ in diameter, but grades upward rather rapidly into finer ophite.

The columnar-jointed trap is exposed on the chain of small islands south of Merritt Lane, on Red Rock Point, and at a few additional isolated localities on the main island. The trap was not seen in actual contact with the upper ophite, for the contact between them apparently is a zone of low resistance to erosion and everywhere occupies a physiographic depression. The trap is considered to be part of the Greenstone Flow, rather than a separate overlying flow, by analogy with the type Greenstone Flow on the Keweenaw Peninsula, where a columnar-jointed "melaphyre" is typically found near the top of the flow (Cornwall, 1951a; 1954a, $\mathrm{b}, \mathrm{c})$. Compositionally the trap on Isle Royale plots closer to the ophite of the Greenstone Flow than to other columnar-jointed trap in the section (fig. 8) on the basis of one analysis of each that is available.

The lower ophite forms the commonly precipitous, antidip slopes on the north side of Greenstone Ridge, whereas resistant pegmatite commonly armors the gentler, south dip slope. The contact between the lower ophite and the pegmatite usually is near the crest of the ridge; because it is a relatively sharp contact, it provides a very useful internal marker horizon, especially for the recognition of offset along faults that cross the ridge. The pegmatitic zone can be traced in outcrop from Blake Point as far west as Mount Desor, west of which outcrops are sparse. Six miles west of Mount Desor, where the flow is perhaps 265 feet thick, the pegmatite appears to be poorly developed, according to Lane's drill log. At the west end of Isle Royale and on Washington Island, the pegmatitic zone appears to be absent. The pegmatitic zone is likewise missing on the Keweenaw Peninsula, at places where the Greenstone Flow is thin (Davidson and others, 1955).

\section{Hill Point Flow}

The Hill Point Flow is a typical ophite useful as a stratigraphic marker only because of its thickness and 
exceptionally coarse grain size; it contains poikilitic augite crystals as much as $2 \mathrm{~cm}$ in diameter. The flow is 158 feet thick near the west end of the island, according to Lane's drill log. It crops out in imposing cliffs along the north shore of the island from Huginnin Cove to McCargoe Cove and then along the south side of Pickerel Cove eastward to Hill Point, the type locality. A few thin seams of pegmatite can be seen near McCargoe Cove, but they are not extensive enough to help in identifying the flow elsewhere.

\section{WASHINGTON IsLAND Flow}

The rock of the Washington Island Flow is difficult to describe but distinctive when seen; perhaps Lane's application of the term "glomeroporphyritic ophite" suggests the problem. The rock is clearly an ophite, as indicated by the poikilitic augite crystals, but the ophitic texture is somewhat obscured by the fact that the plagioclase crystals are somewhat larger than in the typical ophites and have about the same distribution and size within the augite crystals as in the groundmass. Other distinctive features are occasional larger porphyritic plagioclase crystals, about one-half centimeter in average size, and a pervasive greenish speckled appearance caused by the rather uniform distribution of chlorite (fig. 16). In thin section the rock exhibits a relict diktytaxitic texture, chlorite and other secondary minerals filling what appear to have been interstitial voids, as well as replacing earlier minerals, such as olivine.

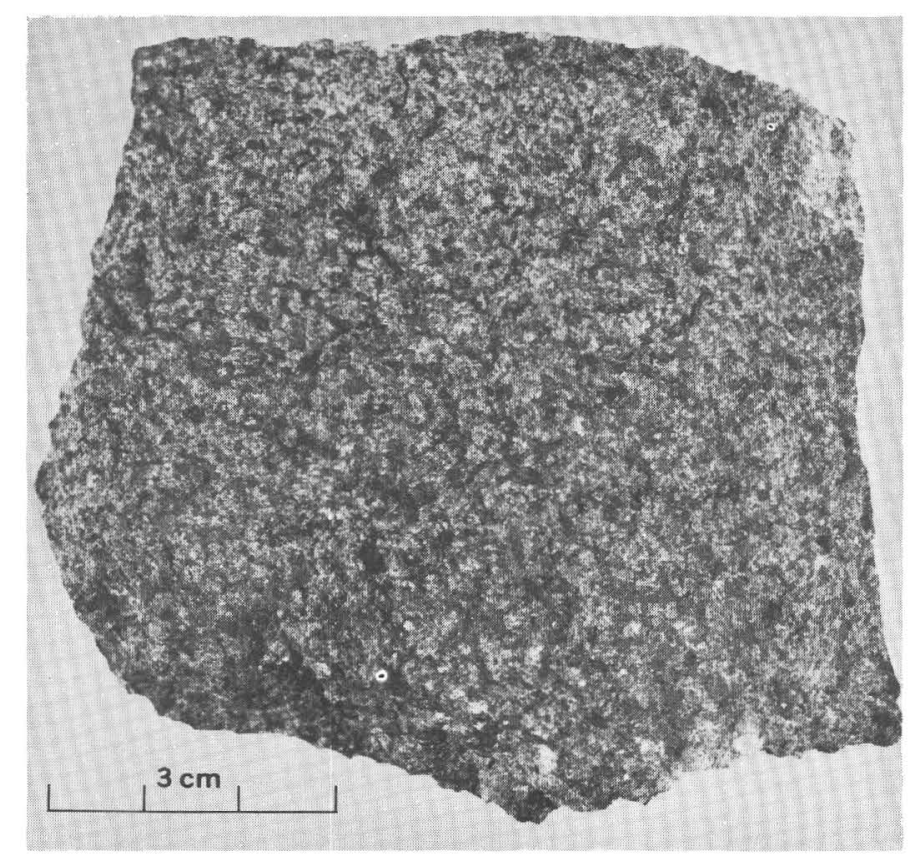

FIGURE 16.-Specimen from Washington Island Flow. Ophitic texture is obscure, but characteristic dark chlorite splotches are visible. Compare with figure $4 A$.
The Washington Island Flow is well exposed at its type locality on the south side of Washington Island, where it caps the highest ridge. On the main island it can be traced eastward from Grace Harbor for about 5 miles, beyond which it appears to pinch out as the Greenstone Flow increases in thickness. A single outcrop of similar rock in the same stratigraphic position above the Greenstone Flow occurs near the east end of the main island on a small point on Porter Island that partially separates a narrow bay from an interior cove. The unit is more than 200 feet thick on Washington Island but thins to about 80 feet 5 miles to the east; it can be no more than a few tens of feet thick on Porter Island.

\section{SEDIMENTARY ROCKS}

Epiclastic sedimentary rocks crop out only in the upper part of the Portage Lake Volcanics, although they are known from drill records to occur lower in the section. Those that crop out are all above the uppermost of the named volcanic units, the Scoville Point Flow, and are best exposed in the Chippewa Harbor area, where seven units of pebble conglomerate and sandstone are interbedded with a series of generally thin ophitic lava flows (fig. 17). These sedimentary units can be traced eastward to a point where most of them disappear beneath the waters of Moskey Basin and Rock Harbor; two are exposed discontinuously on the chain of small islands on the south side of Rock Harbor. All the units can be traced westward from Chippewa Harbor as far as Siskiwit Lake, but farther west outcrops are sparse and correlation of individual units is uncertain. The most accessible outcrops are those in the Chippewa Harbor area, on the south side of Siskiwit Lake, the north side of Conglomerate Bay, the south side of Moskey Basin, and the south side of Mott Island. Conglomerate can been seen on the dumps at the Island Mine, northwest of Siskiwit Bay.

The sedimentary units vary in thickness and in grain size along strike, but on the whole the units seem surprisingly uniform in thickness, considering their probable lateral extent, more than 40 miles. For example, the uppermost unit is predominantly pebble conglomerate for its entire length and appears to thicken eastward very slightly. It is about 30 feet thick west of Siskiwit Bay and at Hay Bay and Chippewa Harbor and increases to about 40 feet on Mott Island. The lower-most sedimentary unit, the Island Mine Conglomerate Bed (Lane, 1898, p. 99), is a pebble conglomerate about 20 feet thick south of Washington Harbor and at the Island Mine and the west end of Siskiwit Lake; it changes to a sandstone also about 20 feet thick at Chippewa Harbor, and it is a sandstone at Moskey Basin, probably slightly thinner. 


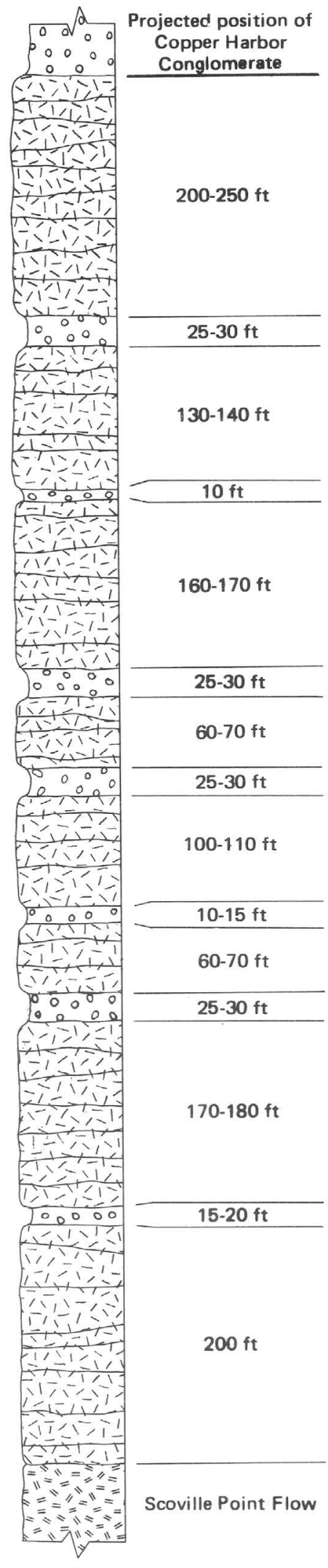

Figure 17.-Columnar section of upper part of Portage Lake Volcanics showing distribution of sedimentary units in the Chippewa Harbor area. All the ophitic flow zones consist of multiple flows.
EXPLANATION $\mid$ The pebbles in the conglomerate are essentially all of volcanic rock, with mafic varieties about twice as abundant as felsic ones. In this respect the conglomerate differs somewhat from the Copper Harbor Conglomerate, higher in the section, where felsic varieties predominate (Wolff and Huber, 1973). The sandstones are very feldspathic, plagioclase being the most abundant among granular constituents. Fine-grained hematite is ubiquitous, giving all the sedimentary rocks a reddish cast and generally obscuring other fine-grained material in the matrix.

The conglomerates and coarser sandstones commonly exhibit a scour-and-fill structure (fig. 18), suggesting an origin in a braided stream system. Locally the sedimentary units are fine-grained even-bedded sandstone throughout and probably represent floodplain deposits. The presence of desiccation cracks and raindrop impressions also point toward a fluvial depositional environment. Paleocurrent data are too scarce to treat statistically, but foreset crossbeds and pebble imbrication suggest that the direction of sediment transport was down the present structural dip, or generally southeast toward the axis of the Lake Superior syncline. This conclusion is compatible with paleocurrent data for the Copper Harbor Conglomerate (Wolff and Huber, 1973).

A sandstone unit below the Long Island Flow, a conglomerate immediately beneath the Greenstone Flow, and several conglomerates below the Hill Point Flow are indicated in Lane's drill log and described as being similar to those mentioned; none of these are known from outcrop.

Another type of rock, with at least a sedimentary component, is one known in the Michigan copper district as a "scoriaceous conglomerate" or "amygdaloid conglomerate," or even "scoriaceous amygdaloid" (Lane,

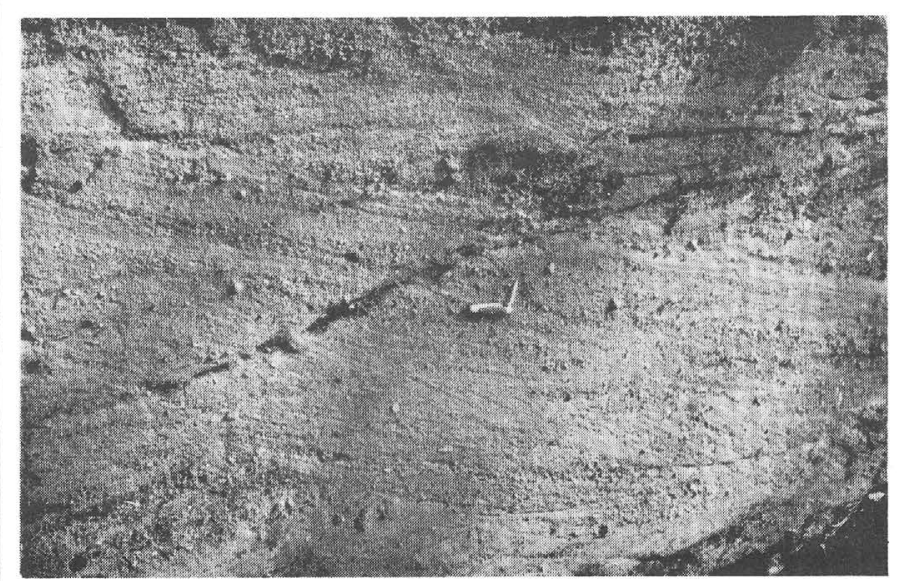

FIGURE 18.-Scour-and-fill structure in pebbly sandstone near the west end of Chippewa Harbor. Handle of penknife approximately $7 \mathrm{~cm}$ long. 
1911, p. 69). This type consists of irregular-shaped fragments of highly amygdaloidal rock or scoria in a matrix of fine sand or silt and might more properly be called a breccia (fig. 19). The percentage of fragments diminishes stratigraphically upward. The rock was formed when fine sedimentary material swept over the fragmental top of a lava flow and incorporated in the resulting deposit various-sized fragments from the underlying flow top. Lane described several units of this type in his Isle Royale drill log, but only one is well exposed at the surface. It occurs immediately above the Amygdaloid Island Flow and can best be seen in a milelong exposure along the south shoreline of Amygdaloid Island near the east end of the island.

\section{PYROCLASTIC ROCKS}

Lane recognized that some of the so-called sedimentary rocks in the Portage Lake Volcanics on Isle Royale are of pyroclastic origin or contain appreciable pyroclastic debris. He referred to these rocks as ash beds and tuffs and described fragments having "the conchoidal forms of glass ash" (Lane, 1898, p. 171-172). Unfortunately, the pyroclastic rocks, like the epiclastic rocks, rarely crop out and are therefore of little use in the field as stratigraphic markers. A tuff-breccia immediately overlying the Greenstone Flow is the single exception; it is exposed sporadically for the length of the island and indeed helps to identify the Greenstone Flow on Washington Island, where that flow is thin

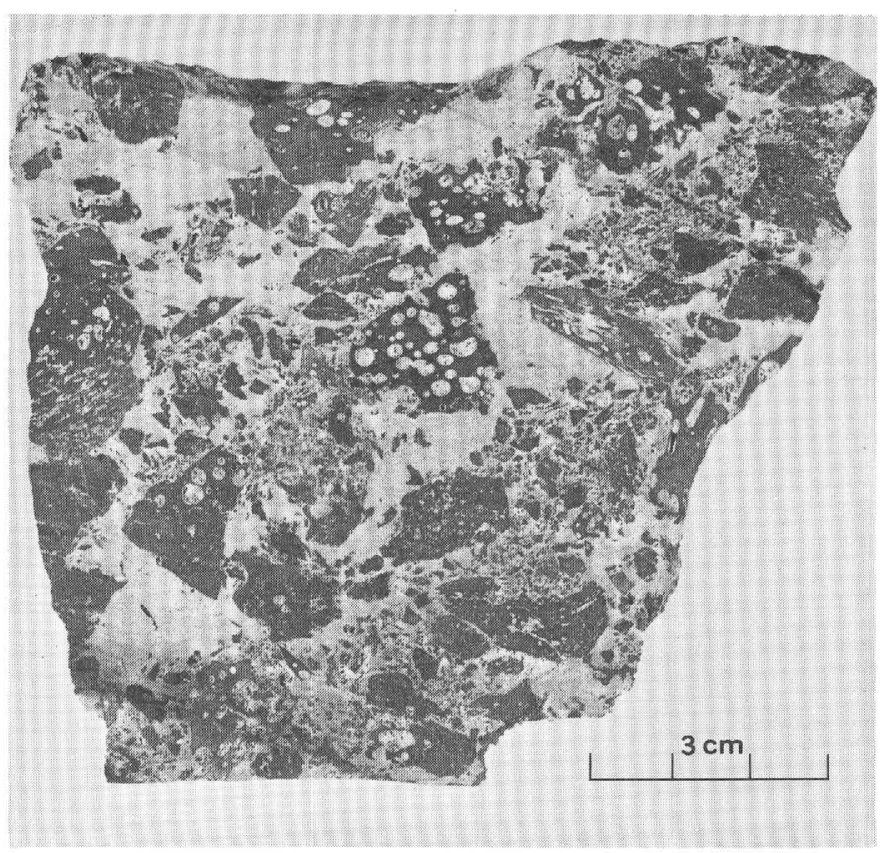

FIGURE 19.-Breccia occurring above the Amygdaloid. Island Flow. Specimen from south shore at east end of Amygdaloid Island. and lacks much of its distinctive character, looking much like any other ophite. Other pyroclastic rocks that occur just above and below the Minong Flow rarely crop out.

The basal part of the tuff-breccia overlying the Greenstone Flow contains much rubble that appears to have been obtained from the Greenstone Flow (fig. 20). Both fragments and matrix within the main body of the tuff are very fine grained, suggesting that much of the rock was originally glassy. Relict shard structures and collapsed pumice fragments are sometimes visible in thin section, and many rock fragments are scoriaceous. Other rock fragments exhibit pilotaxitic texture. Corroded quartz and plagioclase crystals are common, and staining techniques reveal appreciable $\mathrm{K}$-feldspar in the fine-grained matrix, indicating a rather felsic composition. From the east end of the island to Mount Desor, the tuff is also characterized by numerous agates with a pink or red cast (fig. 21). Unlike the ovoid agates typically occurring in many of the volcanic flows, these agates tend to have a very irregular shape similar to the "thunder eggs" occurring in tuffs of the Columbia River Plateau in the Western United States. Such agates have been interpreted by Ross (1941) as chalcedony-filled spherulitic cavities in welded tuff, and their presence in the tuff on Isle Royale, together with other small ellipsoidal vesicles now filled with secondary minerals, suggests that the pyroclastic material was hot when deposited. The tuff where exposed on Washington Island contains quartz and plagioclase crystals, relict shards and pumice, and scoria fragments, but no agates, amygdules, or other evidence of deuteric thermal activity. Perhaps it was far enough away from the pyroclastic source to have been deposited at a lower temperature than the tuff to the east. The most acces-

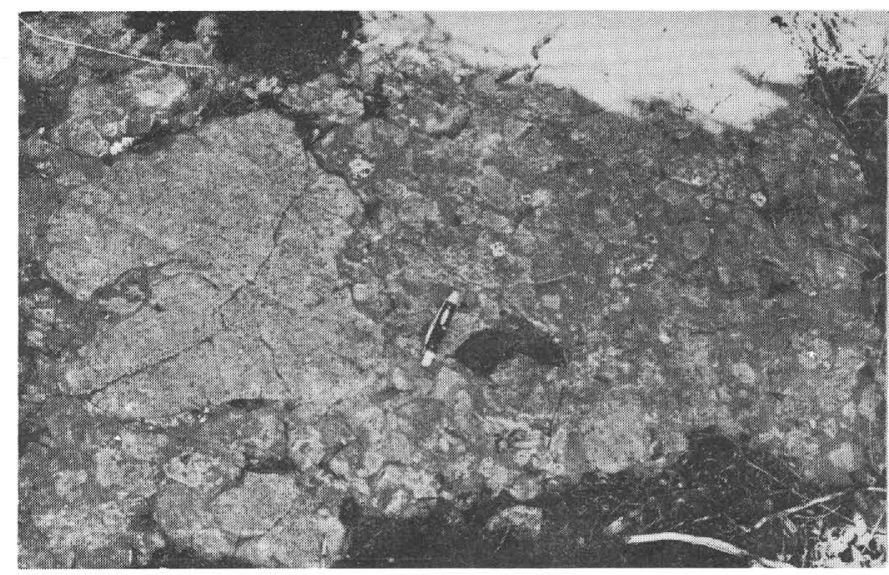

FIGURE 20.-Tuff-breccia overlying the Greenstone Flow. Fragmental character is clearly evident in this outcrop, which is close to the base of the pyroclastic unit on the north shore of Tobin Harbor near Newman Island. Knife, $7 \mathrm{~cm}$ long. 




FIGURE 21.-Agate typical of those occurring in the tuff-breccia overlying the Greenstone Flow. Knife, $7 \mathrm{~cm}$ long.

sible outcrops of the tuff-breccia are on the north side of Tobin Harbor near Newman Island. Its maximum thickness is probably between 25 and 50 feet.

The tuff-breccia above the Minong Flow is similar to that above the Greenstone Flow, with abundant spherulitic structures, some containing agate. This unit is probably the same as Lane's Minong Breccia (or Minong Conglomerate) together with his Minong Porphyrite $(1898$, p. 82, 87). Maximum thickness probably does not exceed 25 feet. The only known exposures of this unit occur in a belt about 1 mile long at the far west end of the island and on the peninsula east of Five Finger Bay at the east end of the island, although it was reported from the workings of the Minong Mine.

Below the Minong Flow a single exposure on a shoreline cliff at the west end of the island shows an ash deposit only a few inches thick in its now-compacted state. It appears to be an air-fall deposit; shard structures are beautifully preserved, and no rock fragments were noted in the few samples examined. The upper part of the ash deposit was later fused by the heat of the overlying Minong Flow, with the downward development of spherulitic structures and the creation of a compaction foliation. A rhyolitic composition is indicated by the refractive index of fused glass beads of the tuff.

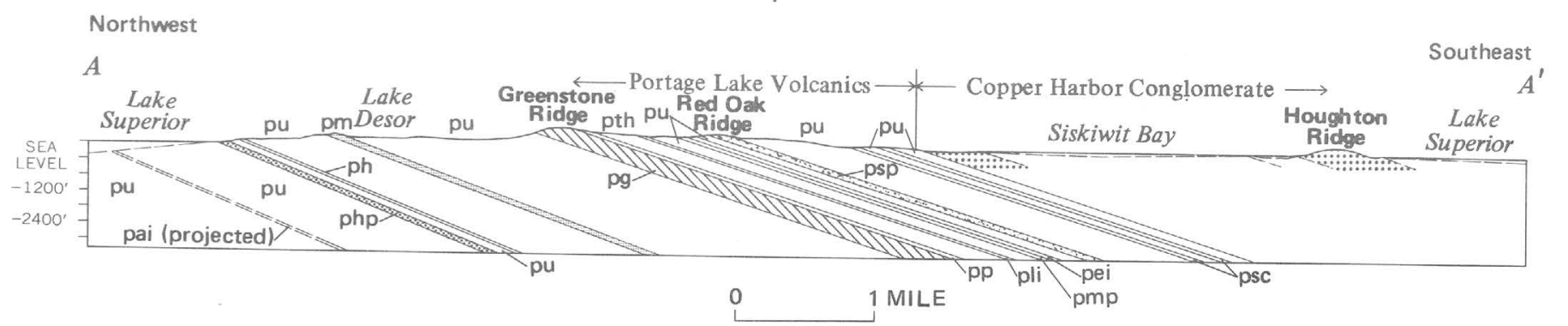

FiguRE 22.-Geologic section of Isle Royale in the vicinity of Lake Desor and Houghton Ridge. Letter symbols represent units
shown in figure 10, with the addition of psc, sandstone and conglomerate; pp, pyroclastic rock; pu, Portage Lake Volcanics,

FiguRE 22.-Geologic section of Isle Royale in the vicinity of Lake Desor and Houghton Ridge. Letter symbols represent units
shown in figure 10, with the addition of psc, sandstone and conglomerate; pp, pyroclastic rock; pu, Portage Lake Volcanics, undivided.

\section{STRATIGRAPHIC SUMMARY}

The individually named flows of the Portage Lake Volcanics on Isle Royale have been described in some detail, along with the other assorted rock types that occur in the sequence. The stratigraphy of the largely volcanic pile has been summarized in a schematic columnar section presented earlier as figure 10, a composite from various parts of the island; not all units shown are everywhere present. Most of the clastic interbeds are known only from drill core, and such data are limited to the western part of the island. The columnar section is not drawn to scale, but some sense of scale can be obtained from the geologic section (fig. 22).

\section{STRATIGRAPHIC THICKNESS}

Some general data have been presented regarding the thickness of individual stratigraphic units, but for most units data on thickness variations along strike are scanty. Because of the hogback asymmetry of ridges formed by individual flows and the tendency of the upper amygdaloidal parts of flows to be eroded, the base rather than the top of most units can be more precisely located even when both contacts are concealed. By utilizing the bases of certain key flows as marker horizons, thickness variations for larger segments of the Portage Lake Volcanics can be calculated for a number of sections across Isle Royale with considerable reliability; the results are presented in a longitudinal stratigraphic section with the base of the Greenstone Flow as a datum plane (fig. 23). Some additional data on the section below the Hill Point Flow, in the vicinity of Amygdaloid Island, have been obtained by tracing on aerial photographs certain topographic lineaments presumed to be stratigraphic horizons.

The longitudinal section brings out two significant features. First, the Greenstone Flow is thickest near the central part of Isle Royale and thins toward both the west and east ends of the island. Secondly, the entire exposed section of the series on Isle Royale also thins toward both ends from a maximum in the center. The Copper Harbor Conglomerate has a similar geundivided. 


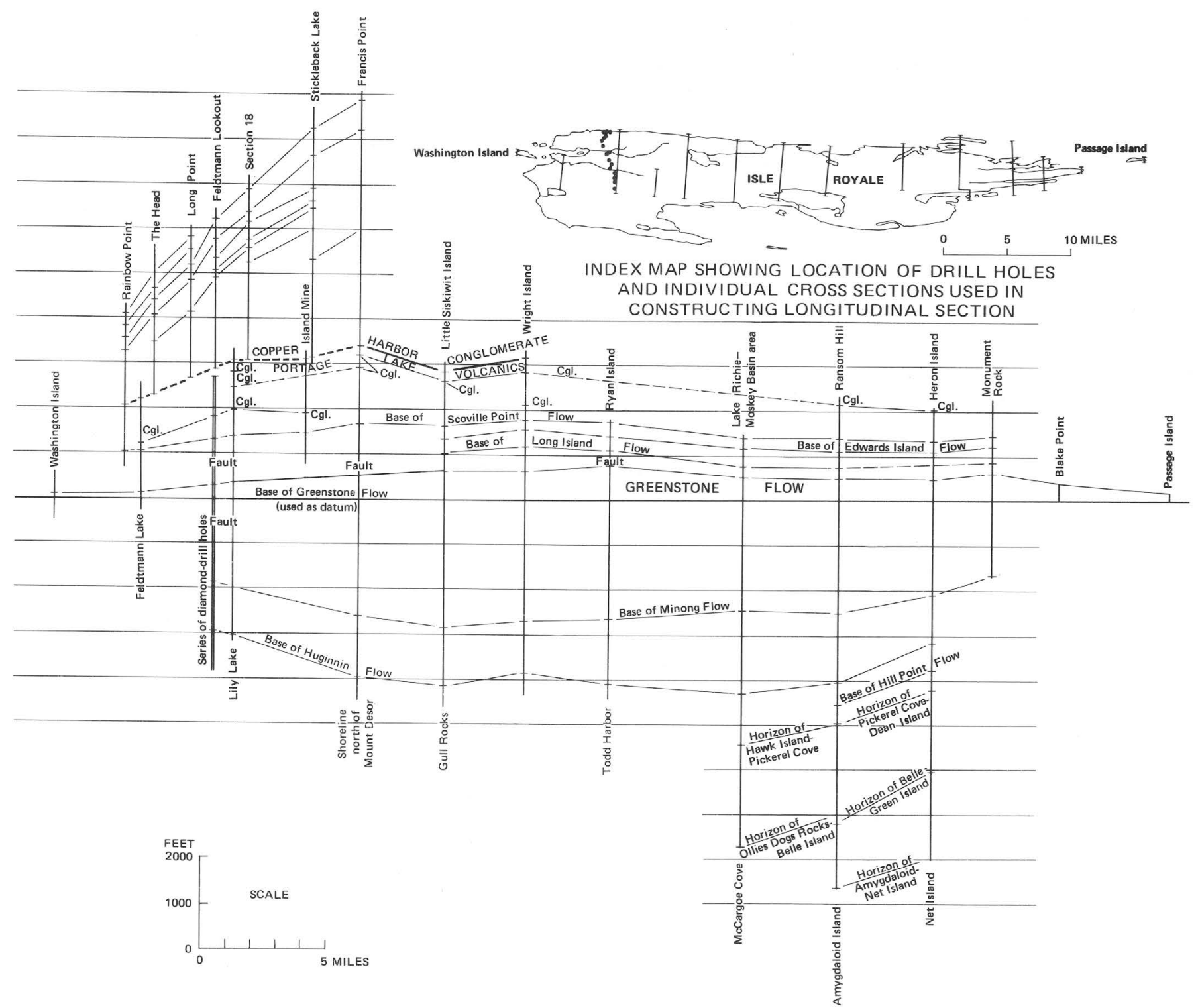

FIGURE 23.-Longitudinal stratigraphic section showing variations in thickness of the Portage Lake Volcanics on Isle Royale. Data on the Copper Harbor Conglomerate from Wolff and Huber (1973).

ometry at the west end of the island. (See Wolff and Huber, 1973, for details.) These features may have some bearing on the topographic expression of Isle Royale as a ridge in the Lake Superior basin, as one would expect the entire section to be more resistant to erosion and stand topographically higher where the individual flows are thickest.

\section{CORRELATIONS}

The Keweenawan volcanic rocks on Isle Royale have long been thought to be correlative with those on the Keweenaw Peninsula, the Portage Lake Volcanics. But all the Keweenawan volcanic rocks exposed around the
Lake Superior basin have at one time or another been thought to be more or less correlative. Only on Isle Royale and the Keweenaw Peninsula, however, is the upper part of the total Keweenawan volcanic sequence both present and in contact with overlying younger formations. At other places around the basin (fig. 1), the basal part of the volcanic sequence is present, including the volcanic rocks of the so-called South Trap Range in westernmost Michigan and Wisconsin, the North Shore Volcanic Group of Green (1971) in Minnesota, and the Osler Group in Ontario. The correlation problem for Isle Royale is thus twofold: (1) to provide a detailed correlation of the volcanic sequence on Isle Royale with the highly similar sequence on the Keweenaw Peninsula and (2) to determine possible overlap between the section on Isle Royale and the 
lower sequences, particularly the North Shore Volcanic Group.

\section{CORRELATION BETWEEN ISLE ROYALE AND THE KEWEENAW PENINSULA}

One of Alfred C. Lane's major contributions to Keweenawan geology was his recognition of the correlation of specific rock units on Isle Royale with their counterparts on the peninsula. In fact, he was not only the first but the only geologist to personally make detailed studies on both Isle Royale and the peninsula.

The key to the correlation is the Greenstone Flow, for as Lane (1911, p. 22) stated, "the backbone of Isle Royale and that of Keweenaw Point is the same lava flow." In each place the Greenstone is the thickest, most persistent flow and is further distinguished by its magmatic differentiation. Henry Cornwall, who studied the Greenstone Flow on the peninsula in great detail and briefly examined the flow on Isle Royale, confirmed their similarities and pointed out that although a few other flows on the peninsula show evidence of differentiation, they differ from the Greenstone Flow in other respects (oral commun., 1971).

Even more convincing than mere similarities between the "backbone" of Isle Royale and that of the Keweenaw Peninsula, however, are the similarities in the entire rock sequence in the two areas, including the position of the Greenstone Flow within the sequence. It was Lane's recognition of these broader similarities that strengthened his arguments for correlation.

Very thick flows like the Greenstone Flow are the exception, however, for while it does specifically correlate across Lake Superior, to suggest that all the flows in the Portage Lake Volcanics are continuous across the lake would be unrealistic. But different rock types were produced at different times during the volcanic cycle, and both Isle Royale and the Keweenaw Peninsula show parallel sequences of similar types, the part of the sequence above the Greenstone Flow providing the clearest correspondence.

The flows above the type Greenstone Flow on the Keweenaw Peninsula were previously divided into two groups, the Ashbed Group of Irving (1883) and the overlying Eagle River Group of Lane and Seaman (1907), both of which Lane thought he recognized on Isle Royale. On the island the Ashbed Group would include the rocks from the top of the Greenstone Flow to the top of the Scoville Point Flow, and the Eagle River Group, those from the top of the Scoville Point Flow to the top of the Portage Lake Volcanics. Although these formal group names are no longer generally used, they were applied to sections on the peninsula almost directly across from Isle Royale and are still useful for purposes of discussion.
Correlation criteria for the Ashbed Group are as follows:

1. At the base of the Ashbed Group just above the Greenstone Flow on the peninsula is the Mesnard Epidote of Lane and Seaman (1907, p. 680), described as a "volcanic ash" by Lane $(1911$, p. 37, 688 ). The tuff-breccia immediately above the Greenstone Flow on the island is in the same stratigraphic position.

2. The Washington Island Flow is unique in appearance on the island and has its counterpart in the Pewabic Flow in the same relative position on the peninsula (Lane, 1911, p. 689; Cornwall, oral commun., 1971).

3. The Ashbed Group "is characterized by lavas which contain more soda than the regular ophites and which are relatively feldspathic and fine grained [porphyrites and glomeroporphyrites]" (Lane, 1911, p. 35). These flows occur in three distinct zones in the Ashbed Group on the Keweenaw Peninsula (for example, see Davidson and others, 1955), and the middle zone contains the type Ashbed Flow. The three zones are represented on Isle Royale by the Tobin Harbor, Middle Point, and Scoville Point Flows. In fact, at least part of the Middle Point Flow of this report was specifically correlated with the Ashbed Flow by Lane (1911, p. 670).

4. On the Keweenaw Peninsula "columnar basalt occurs only in two flows, the Greenstone and a 'melaphyre' just above the Ashbed Flow" (Cornwall, 1954b). As noted earlier, on the island the Greenstone Flow is interpreted as having a columnar-jointed zone, and the columnar-jointed Edwards Island Flow appears to be in the same stratigraphic position as the "melaphyre." The other columnar-jointed flow on the island, the Long Island Flow, which lies between the Tobin Harbor and Middle Point Flows, is in the same stratigraphic position as some fine-grained melaphyres on the peninsula. Columnar jointing can be seen in only a few of the outcrops of the Long Island Flow, however, and it is possible that similar but concealed jointing occurs in the probable equivalent rocks on the peninsula, where they are largely known only from drill core.

The uppermost group, the Eagle River Group of Lane and Seaman (1907), has been described on the Keweenaw Peninsula as "characterized by waning volcanic activity. It contains numerous sandstones and conglomerates, and on the whole they are more rounded in this group than in others. The individual lava flows are generally not thick nor coarse grained" (Lane, 1911, p. 37). The rocks are also generally ophitic. This description also accurately fits the upper part of the Portage Lake Volcanics on Isle Royale, that part above the Scoville Point Flow (fig. 17). 
Below the Greenstone Flow it is more difficult to make specific correlations of volcanic units. On both sides of the Lake Superior syncline, flows of the lower part of the Portage Lake Volcanics are chiefly ophitic, including a number with above-average thickness. The thick Hill Point Flow on the island could well be correlative with a thick ophitic flow such as the Scales Creek Flow (fig. 3) on the peninsula, as suggested indirectly by Lane (1911, p. 739), but such a correlation is only one of several options. Equivalents of the other stratigraphic markers on the island have not been recognized on the peninsula.

Several bodies of felsite occur in the lower part of the Portage Lake Volcanics near the east end of the Keweenaw Peninsula, at and below the horizon of the Bohemia Conglomerate (fig. 3). This would be in the upper part of the Bohemian Range Group of the older terminology. The body at Bare Hill, for example, is a fine-grained reddish-brown rhyolite that contains scattered feldspar phenocrysts as much as 2 millimeters long and is considered to be an extrusive dome (Cornwall, 1954c). A felsite reported to be lithologically similar to that of Bare Hill was intersected at the very bottom of a hole drilled at the north shoreline of Isle Royale (Lane, 1911, p. 755); projection of the felsite would reach the surface of Lake Superior about $13 / 4$ miles offshore. This felsite, together with some thick felsite-pebble conglomerates above it, led Lane to suggest that its correlative stratigraphic position on the peninsula might lie within the upper part of the Bohemian Range Group at the approximate horizon of the Bohemia Conglomerate (Lane, 1911, p. 749).

Correlation of the Greenstone Flow on opposite sides of Lake Superior, or at least correlation of its relative position in the stratigraphic sequence, is also supported by paleomagnetic evidence. Books (1972) determined paleomagnetic field orientations for a cross section of the Portage Lake Volcanics near Calumet on the Keweenaw Peninsula. He found that the field directions are fairly uniform throughout the sequence, except for an anomalous variation that occurs just below the Greenstone Flow. He found an identical field variation just below the Greenstone Flow on Isle Royale.

The clastic deposits within the Portage Lake Volcanics are chiefly stream deposits laid down on top of what were essentially flat-lying lava flows within the volcanic sequence. Although these conglomerates and sandstones are lenticular rather than continuous sheets, their horizons can be carried across many of the gaps in their continuity. In places where the beds are missing, their horizons generally can be recognized in drill core by detrital material in the underlying amygdaloidal flow top, and as a result, the sedimentary units provide excellent horizon markers within the

Portage Lake Volcanics where subsurface data are available (White, 1968).

If the period of volcanic quiescence during which the sedimentary rocks were deposited was basin wide, then coeval, if not connected, sedimentary deposits might exist on opposite sides of the basin, even though differences in source areas might create dissimilarities in the deposits. On this assumption, Lane attempted to correlate individual sedimentary units on Isle Royale with the well-established sequence on the peninsula, utilizing both the nature and relative position of the sedimentary units and the nature of the intervening lava flows. In view of the general lack of outcrop of the sedimentary rocks, the attempt itself would not have been possible without the data from the series of exploratory holes drilled across the island.

If Lane's correlations are accepted (table 2), which is not unreasonable, they can be used to compare rela-

TABLE 2.-Correlation of clastic units in the Portage Lake Volcanics between the Keweenaw Peninsula and Isle Royale

Keweenaw Peninsula
(for strat. section, see fig. $s$ )

Hancock Conglomerate (No. 17).

Pewabic West Conglomerate (No. 16).

Mesnard Epidote of Lane and Seaman (1907).

Allouez Conglomerate (No. 15).

Houghton Conglomerate (No. 14).

Calumet and Hecla Conglomerate (No. 13).

Kingston Conglomerate (No. 12) (=Kearsarge Conglomerate of Lane).

Wolverine Sandstone (No. 9)_ _ Very thin sandstone bed $350 \mathrm{ft}$ Bohemia Conglomerate (No. 8).

1On Isle Royale only the two indicated tuff-breccias are known from outcrop. Correlation of clastic units between Keweenaw Peninsula and the Isle Royale drill records is by Lane (1898); correlation of named lava flows on Isle Royale with Lane's drill log is by Huber (this report).

tive thicknesses of groups of flows on Isle Royale and the Keweenaw Peninsula, as in figure 24. For Isle Royale, one stratigraphic section $(A)$ was obtained directly from Lane's drill log. By using key volcanic units as control, another section $(B)$ was obtained from extrapolating the relative position of the sedimentary units in the drill core to the stratigraphic section near Wright Island (fig. 23). The stratigraphic diagram dis- 
regards structural considerations and the probability that the formation is thickest in the central part of the Lake Superior basin and thins in both directions toward Isle Royale and the peninsula; thus the "planes" in the illustration are very artificial and are used only to tie the individual stratigraphic sections together.

The thickness of the upper part of the sequence is somewhat similar on both sides of Lake Superior, but the lower part becomes increasingly thicker on the peninsula than on Isle Royale. This difference in the lower part would suggest that the measured stratigraphic sections on the peninsula were perhaps closer to the axis of the subsiding depositional basin than the sections on Isle Royale (fig. 1). Such an interpretation is supported by geophysical evidence (for example, White, 1966b; Wold and Ostenso, 1966).

The thickest equivalent sections on Isle Royale and the peninsula occur where the distance between the two belts of the Portage Lake Volcanics on opposite sides of the basin is the least-near the central part of the island and near the Cliff mine on the peninsula ( $B-D$ in fig. 24). Local thickness of the section probably bears some relation to distance from the margin of the original depositional basin. This relation is indicated for at least the west end of Isle Royale by the fact that there the Portage Lake Volcanics thins toward the west- the direction from which the clastic debris in the overlying thick wedge of Copper Harbor Conglomerate was derived, as shown by various criteria indicating direction of sedimentary transport (Wolff and Huber, 1973). As this fluvially deposited conglomerate contains boulders as much as 2 feet in diameter, its source area could not have been far.

\section{RELATION TO OTHER KEWEENAWAN VOLCANIC ROCKS}

The Portage Lake Volcanics on Isle Royale represents, as noted, the uppermost part of the Keweenawan volcanic sequence on the north side of Lake Superior, and the North Shore Volcanic Group of Green (1971) and the Osler Group represent the lowermost part. In Minnesota the North Shore Volcanic Group overlies lower Keweenawan sedimentary rocks (Puckwunge Formation of Winchell, 1897). In Ontario the Osler Group has not been studied in detail, but as it overlies lower Keweenawan sedimentary rocks (Sibley Group), it is probably at least in part correlative with the North Shore Volcanic Group. Correlation is also supported by the fact that a reversely polarized paleomagnetic field with similar orientation exists in the lower parts of the Osler Group and the North Shore Volcanic Group as well as in the volcanic rocks of the South Trap Range (Books, 1968, 1972; Halls, 1972; Palmer, 1970). Al-

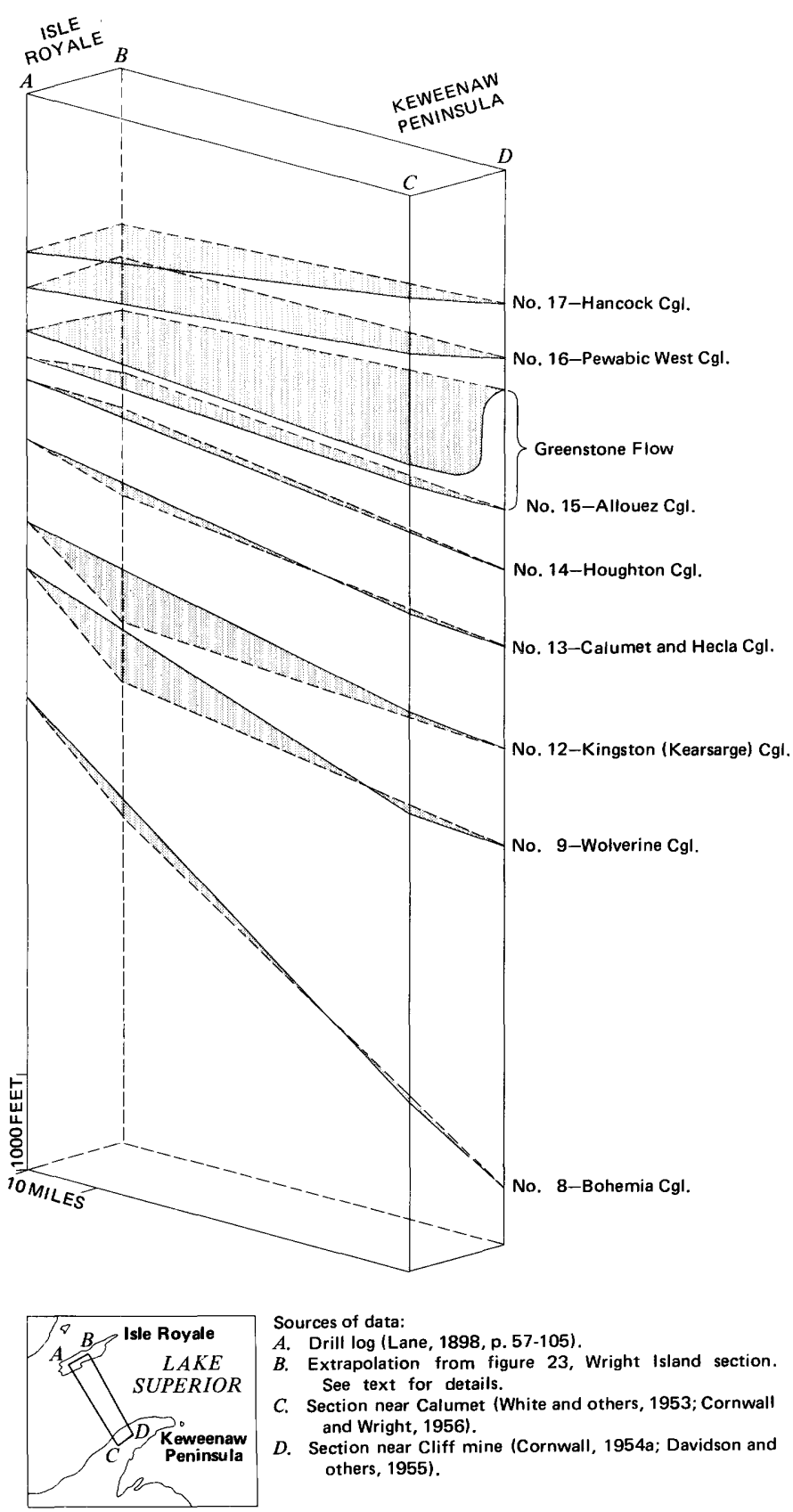

FIGURE 24.-Stratigraphic diagram illustrating correlation of sedimentary horizons in the Portage Lake Volcanics between Isle Royale and the Keweenaw Peninsula. Numbers and names are those used on the peninsula. (See fig. 3.)

though all these volcanic rocks have traditionally been assigned to the middle Keweenawan, along with the Portage Lake Volcanics, it has been suggested that perhaps the lowermost ones, those reversed ones below the horizon of the paleomagnetic change to normal polarity, should be designated as lower Keweenawan (for example, Books, 1968; Green and Books, 1972). The exposed section of the Osler Group may be as much as 10,000 feet thick (Tanton, 1931); that of the North 
Shore Volcanic Group is approximately 23,000 feet thick (Green, 1971).

The Portage Lake Volcanics and the North Shore Volcanic Group do not appear to overlap stratigraphically. Overlap cannot be completely ruled out, however, as ophitic basalts do occur both at the top of the exposed North Shore Volcanic Group and at the base of the exposed Portage Lake Volcanics. Further, we have no knowledge of the composition or thickness of the unexposed portions of each sequence beneath Lake Superior. The major difference between the two stratigraphic sections is that felsic volcanic rocks are nearly absent from the Portage Lake Volcanics, whereas they are relatively abundant in the North Shore Volcanic Group (Green, 1971). Andesites also may be more abundant in the North Shore Volcanic Group.

Other evidence suggests a stratigraphic break of some sort between the two volcanic sequences, although interpretation is far from unequivocal. The low degree of metamorphism and lack of schistosity of the volcanic clasts in the sedimentary rocks interbedded with the lava flows in the Portage Lake Volcanics and in the Copper Harbor Conglomerate on Isle Royale are typical of Keweenawan volcanic rocks and unlike any pre-Keweenawan rocks in the Lake Superior region. The North Shore Volcanic Group is the most likely source terrane for this clastic debris. This conclusion requires that at least part of the North Shore Volcanic Group, including both felsic and mafic volcanic rocks, be exposed and subjected to active erosion at the margin of the depositional basin, while volcanic activity continued in the central part of the basin during the formation of the Portage Lake Volcanics. An unconformity between the North Shore Volcanic Group and the Portage Lake Volcanics, as suggested by Wolff and Huber (1973), would account for such erosion of the lower sequence. Or it is possible that part of the North Shore Volcanic Group was tectonically uplifted at the margin of the basin and that consequently the Portage Lake Volcanics was deposited in progressively smaller areas in the central part of the basin as uplift proceeded. It is also possible that the North Shore Volcanic Group and the Portage Lake Volcanics formed in separate tectonic basins isolated from each other, rather than in a single large basin, as has been suggested for some of the Keweenawan volcanic sequences on the south side of the Lake Superior basin (White, 1966a; White and others, 1971). Finally, it is possible that there is a major stratigraphic break within the North Shore Volcanic Group at the approximate horizon of the paleomagnetic reversal. In such a case, the greater part of the North Shore Volcanic Group, with normal polarity, could be continuous upward into the Portage Lake Volcanics, with the necessary clastic debris for middle Keweenawan sedimentary rocks being derived from only the lower part of the North Shore Volcanic Group, where the required rock types are apparently present (Green, 1971; Green and Books, 1972).

Each of these structural settings would permit erosion of at least part of the North Shore Volcanic Group to provide clastic debris for younger Keweenawan sedimentary rocks. It is hoped that future work will provide evidence for narrowing the choice.

\section{STRUCTURE}

The layered bedrock sequence on Isle Royale is tilted toward the southeast. Dips of the strata range from less than $10^{\circ}$ to $55^{\circ}$; they are generally steeper on the north side of the island than on the south side and average less than $20^{\circ}$. The increase in dip toward the north side is probably related in part to increasing proximity to the Isle Royale fault in that direction (fig. 1). The existence of a high-angle thrust fault along the north side of Isle Royale, similar to the well-documented Keweenaw fault on the Keweenaw Peninsula, was postulated on physiographic grounds by Irving and Chamberlain (1855). Considerable geophysical evidence has since been marshalled in support of its existence (Wold and Ostenso, 1966; Halls and West, 1971), and Halls and West estimated that the southeast side has been upthrown at least 1-2 kilometers. The structural setting of Isle Royale is thus analogous to that on the Keweenaw Peninsula, where dips increase markedly toward the Keweenaw fault; dips exceeding $30^{\circ}$ are found only within 4 or 5 miles of the Keweenaw fault (White, 1968). A slight flexure in the strata between McCargoe Cove and Pickerel Cove on the northeast end of Isle Royale also may be related to movement on the Isle Royale fault.

The only major distortion superimposed upon the homoclinal structure of Isle Royale is in the area between Siskiwit Lake and Rock Harbor, where the upper part of the Portage Lake Volcanics is warped around a node of apparent uplift and fracturing. The style of deformation there is different on opposite sides of a fault that extends through Chippewa Harbor and Lake Richie. On the southwest side of that fault, the stratigraphic units from the Edwards Island Flow upward, though cut by numerous minor faults, all swing with relative continuity around a point centered near the south end of Lake Richie. On the northeast side, only the stratigraphically highest sedimentary units in the Portage Lake Volcanics maintain continuity. The volcanic sequence between those units and the Scoville Point Flow is broken by a series of closely spaced normal faults trending parallel to the strike direction of the flows and consistently downthrown on the north, 
resulting in extreme duplication of that part of the stratigraphic section.

Lane (1898, p. 210), in discussing this area, noted that "the strata appear as though wrapped over some large mass below" and that "this suggests either that there is an intrusion below or that we are on the flanks of an old volcanic focus." In support of this suggestion, he cited the presence of thin "apparently intrusive sills," which in the present study are interpreted as pegmatitic differentiates of extrusive volcanic rocks; no intrusive rocks are now thought to be exposed in the area. Nevertheless, the area seems to have been domed upward, and it is possible that a buried intrusive was the cause.

Lane's map of this deformed area is somewhat misleading and can be interpreted as indicating an appreciable nontectonic thickening of the stratigraphic section in the Lake Richie-Chippewa Harbor region, an interpretation made by Halls and West (1971, p. 622), among others. Lane was aware of the limitations of his map, however, when he stated that "I can hardly hope to have connected all the isolated outcrops exactly" (Lane, 1898, p. 209). Geologic mapping during the present study indicates that what appears to be stratigraphic thickening on Lane's map is due partly to decrease in dip of the strata in the central part of the upwarped zone and partly to extensive duplication of section by a complex pattern of normal faults. Consequently, the outcrop pattern is strongly influenced by topography, and the map pattern of the thin sedimentary units gives the impression of a more complex structure than actually exists. It is only fair to state that most of the refinements of the present mapping were made possible solely through the use of resources unavailable to Lane, in particular modern aerial photographs and modern mosquito repellent that permitted the field use of those photographs.

Topographic lineaments and smaller scale fractures related to a regional fracture system are superimposed upon the homoclinal structure. One prominent joint set of this system trends northward at the west end of Isle Royale and changes progressively eastward to trend about $30^{\circ} \mathrm{E}$. of $\mathrm{N}$. at McCargoe Cove. Minor faulting has occurred along some of the lineaments related to this set, but displacements are generally small and probably rarely exceed 100 feet. All displacement appears to be near vertical, with the east side upthrown relative to the west side. Some fractures of a second set, trending east-west, commonly are faults showing somewhat greater displacements but still no more than a few hundred feet. Displacements along this set also are vertical, with the south side upthrown relative to the north side. The systematic orientation and nature of displacement of these fracture sets attest to the regional nature of their pattern. The fractures were probably formed in response to warping of the bedrock strata on the flank of the Lake Superior syncline, probably in part caused by thrust movement on the Isle Royale fault.

\section{ORIGIN OF THE PORTAGE LAKE VOLCANICS}

The Portage Lake Volcanics is the upper part of the total Keweenawan volcanic sequence, one of the world's major accumulations of plateau or flood basalt flows. This sequence, together with the associated Keweenawan continental red clastic rocks, is probably more than 40,000 feet thick locally. These materials fill a trough or series of elongate basins nearly 100 miles wide and more than 1,000 miles long, coincident in part with the midcontinent and mid-Michigan high gravity and magnetic anomalies (Bayley and Muehlberger, 1968). The structure has been interpreted as a major rift system of continental proportions. (See, for example, Hinze and others, 1971; King and Zietz, 1971; Lyons, 1970; Pettijohn, 1970.)

The source of the lavas appears to have been along the axis of the trough or rift system, as directional flow data on the Keweenaw Peninsula indicate flow from the Lake Superior basin toward the peninsula, and the Portage Lake Volcanics has been interpreted as wedging out completely within 15-20 miles south of the present line of outcrop of the sequence on the peninsula (White, 1960). On the north shore of Lake Superior in Ontario, Tanton (1931, p. 64) noted that in a number of localities flowage wrinkles on the tops of lava flows in the Osler Group indicated flowage toward the north or northeast prior to consolidation. He concluded that "all observations indicate that the lava came from a southerly source and it seems probable that the lava was poured out along fissures in the site of Lake Superior." Although the Osler Group is probably stratigraphically below the Portage Lake Volcanics on Isle Royale, the two sequences appear to have many similarities, and no reason now indicates that the lavas came from different sources. Definitive directional flow data are lacking on Isle Royale, but stratigraphic considerations previously mentioned suggest that the Isle Royale vicinity was not far from the northwest margin of the depositional basin at the time the Portage Lake Volcanics was erupted. Assuming this location, there is almost no alternative but that great volumes of lava were erupted from fissures near the axis of the trough and spread laterally and rapidly toward both margins of the trough, finally ponding and cooling in place to form vast sheets covering literally thousands of square miles. 
White (1960,p. 372-373) summed up the mechanism of basalt flooding as follows:

The principal consequence of the great volume of lava floods is that on a relatively flat surface a flow may come approximately to rest while its interior, at least, is still molten, giving the top time to approach a hydrostatic level. The near-level surface of such a flow provides the floor for a succeeding flow, making the upper and lower surfaces of successive flows nearly parallel over large areas. As envisaged here, the formation of a basalt flood has its closest observed counterpart in the initial burst of lava from vents on shields. The great volume of lava and the gentle slope keep the flow thick, molten, and exceedingly wide, and do not permit the top to become anchored or tunnels to form. Motion stops primarily because the lava is ponded, either against an uphill slope or behind the dam of its own frozen margin. After eruption ceased, there would, of course, be some movement of lava from central to marginal parts of the flow, and some local advances of the front itself as long as the leveling process continued, but these movements would be minor compared with those of the initial flooding. The crystallization of a large part of the interiors of flows would thus take place under essentially static conditions.

White arrived at his interpretation largely on the basis of field evidence, speculating that the great volume of lava alone, rather than an abnormally high fluidity, favored the formation of flood basalts instead of the construction of shield volcanoes of the Hawaiian type, which are made up of rock types that do not differ greatly.

Shaw and Swanson (1970a, b) recently calculated some eruption and flow rates for flood basalts on the basis of certain physical parameters for the Yakima Basalt flows of the Columbia River Plateau and measured viscosity data for Hawaiian basalt. They (1970a) concluded the following:

Fluid dynamical calculations suggest average flow velocities in the turbulent regime of 10 to $20 \mathrm{~km}$ per hour for flows of about $10 \mathrm{~m}$ or more in thickness assuming average effective viscosities of approximately 500 poises. Such velocities indicate that heat loss during flow was mainly by radiation, and that lavas $200 \mathrm{~km}$ from their source cooled an average of about $50^{\circ} \mathrm{C}$ during flow. Turbulent flow implies homogeneity of flow units and little development of surface crust during movement, and the small temperature depression during flow implies that quenched lavas would have low crystal contents if they were initially at or above their liquidus. Both implications are consistent with field studies.

They further concluded that with only minor and altogether realistic changes in their assumptions, chiefly somewhat larger source fissures, surface flow rates approaching $50 \mathrm{~km}$ per $\mathrm{hr}$ can be calculated. The field evidence suggesting rapid eruption and flowage, with ponding and cooling in place, is not inconsistent with theoretical flow mechanics.

Data from the Keweenaw Peninsula and Isle Royale indicate that the clastic debris in the sedimentary rocks interbedded with the lava flows of the Portage Lake Volcanics and in the Copper Harbor Conglomerate and other Keweenawan formations above the lava sequence was transported into the basin from marginal source terranes (White, 1952, 1960; White and Wright, 1960; Hamblin and Horner, 1961; Wolff and Huber, 1973). The evidence for basinward flow of streams, contrasted with evidence that the lavas flowed toward the margins of the basin, shows that there were at times reversals of the prevailing slope over large areas, and the picture of a basin subsiding as it was filled seems established beyond any reasonable doubt. According to White's analysis (1960), the lava was horizontal or sloped gently toward the margins of the basin as long as filling kept pace with downwarping. When extrusion was interrupted, however, downwarping produced basinward slopes over small to large areas, permitting sedimentary debris to be swept into the basin during those periods of volcanic quiescence. Finally, with the gradual cessation of volcanic activity, continued subsidence permitted the accumulation of the Copper Harbor Conglomerate and younger deposits to form a thick sedimentary sequence in the basin.

The gross synclinal form of the Keweenawan basin resulted from subsidence coincident with filling of the basin rather than later folding. However, attitudes of strata near the margins of the basin, as on the Keweenaw Peninsula and Isle Royale, were subsequently steepened by movement on major thrust faults, the Keweenaw fault and the Isle Royale fault, thereby accentuating the synclinal structure.

\section{REFERENCES CITED}

American Commission on Stratigraphic Nomenclature, 1970, Code of stratigraphic nomenclature: Tulsa, Okla., Am. Assoc. Petroleum Geologists, 19 p.

Bayley, R. W., and Muehlberger, W. R., compilers, 1968, Basement rock map of the United States, exclusive of Alaska and Hawaii: U.S. Geol. Survey, 2 sheets, scale 1:2,500,000.

Books, K. G., 1968, Magnetization of the lowermost Keweenawan lava flows in the Lake Superior area, in Geological Survey research 1968: U.S. Geol. Survey Prof. Paper 600-D, p. D248-D254.

-1972, Paleomagnetism of some Lake Superior Keweenawan rocks: U.S. Geol. Survey Prof. Paper 760, 42 p.

Broderick, T. M., 1935, Differentiation in lavas of the Michigan Keweenawan: Geol. Soc. America Bull., v. 46, p. 503-558.

Broderick, T. M., Hohl, C. D., and Eidemiller, H. N., 1946, Recent contributions to the geology of the Michigan copper district: Econ. Geology, v. 41, no. 7, p. 675-725.

Bulter, B. S., and Burbank, W. S., 1929, The copper deposits of Michigan: U.S. Geol. Survey Prof. Paper 144, 238 p.

Cornwall, H. R., 1951a, Differentiation in lavas of the Keweenawan Series and the origin of the copper deposits of Michigan: Geol. Soc. America Bull., v. 62, p. 159-202.

-1951b, Differentiation in magmas of the Keweenawan Series: Jour. Geology, v. 59, no. 2, p. 151-172.

1954a, Bedrock geology of the Phoenix quadrangle, Michigan: U.S. Geol. Survey Geol. Quad. Map GQ-34, scale 1:24,000. 
1954b, Bedrock geology of the Delaware quadrangle, Michigan: U.S. Geol. Survey Geol. Quad. Map GQ-51, scale $1: 24,000$.

1954c, Bedrock geology of the Lake Medora quadrangle, Michigan: U.S. Geol. Survey Geol. Quad. Map GQ-52, scale $1: 24,000$.

Cornwall, H. R., and Wright, J. C., 1956, Geologic map of the Laurium quadrangle, Michigan: U.S. Geol. Survey Mineral Inv. Field Studies Map MF-47, scale 1:24,000.

Davidson, E. S., Espenshade, G. H., White, W. S., and Wright, J. C., 1955, Bedrock geology of the Mohawk quadrangle, Michigan: U.S. Geol. Survey Geol. Quad. Map GQ-54, scale $1: 24,000$.

Foster, J. W., and Whitney, J. D., 1850, Report on the geology and topography of a portion of the Lake Superior Land District in the State of Michigan; Part 1, Copper Lands: U.S. 31st Cong., 1st sess, House Ex. Doc. 69, 224 p.

Green, J. C., 1971, The North Shore Volcanic Group, in Inst. Lake Superior Geology, 17th Ann., 1971, Abs. and Field Guides: Duluth, Minn., p. 74-96.

Green, J. C., and Books, K. G., 1972, Paleomagnetic evidence for the extent of lower Keweenawan lavas in Minnesota [abs.], in Inst. Lake Superior Geology, 18th Ann., 1972, Abs. and Field Guides, Paper 8: Houghton, Mich.

Halls, H. C., 1966, A review of the Keweenawan geology of the Lake Superior region, in The earth beneath the continents - a volume of geophysical studies in honor of Merle A. Tuve: Am. Geophys. Union Geophys. Mon. 10 (Natl. Acad. Sci., Natl. Research Council Pub. 1467), p. 3-27.

1972, Magnetic studies in northern Lake Superior: Canadian Jour. Earth Sci., v. 9, p. 1349-1367.

Halls, H. C., and West, G. F., 1971, A seismic refraction survey in Lake Superior: Canadian Jour. Earth Sci., v. 8, p. 610630.

Hamblin, W. K., and Horner, W. J., 1961, Sources of the Keweenawan conglomerates of northern Michigan: Jour. Geology, v. 69, p. 204-211.

Hinze, W. J., Davidson, D. M., and Roy, R. F., 1971, Continental rifts [abs.], in Inst. Lake Superior Geology, 17th Ann., 1971, Abs. and Field Guides: Duluth, Minn., p. 29.

Houghton, Douglas, 1841, [Fourth] annual report of the State Geologist: Michigan House of Representatives [Doc.] no. $27,184 \mathrm{p}$.

Hubbard, H. A., 1968, Stratigraphic relationships of some Keweenawan rocks of Michigan and Wisconsin [abs.], in Inst. Lake Superior Geology, 14th Ann., 1968, Superior, Wisc., p. 35-36.

Huber, N. K., 1973a, Glacial and postglacial geologic history of Isle Royale National Park: U.S. Geol. Survey Prof. Paper 754-A, 15 p.

1973b, Geologic map of Isle Royale National Park: U.S. Geol. Survey Misc. Geol. Inv. Map. I-796, scale 1:62,500.

Irvine, T. N., and Baragar, W. R. A., 1971, A guide to the chemical classification of the common volcanic rocks: Canadian Jour. Earth Sci., v. 8, p. 523-548.

Irving, R. D., 1883, The copper-bearing rocks of Lake Superior: U.S. Geol. Survey Mon. 5, 464 p.

Irving, R. D., and Chamberlin, T. C., 1885, Observations on the junction between the Eastern Sandstone and the Keweenaw Series on Keweenaw Point, Lake Superior: U.S. Geol. Survey Bull. 23, $124 \mathrm{p}$.

Jackson, C. T., 1849, Geological and mineralogical reports: U.S. 31st Cong., 1st sess., House Ex. Doc. 5, p. 371-935.

Jackson, K. C., 1970, Textbook of lithology: New York, McGraw-Hill Book Co., 552 p.
James, H. L., 1972, Subdivision of Precambrian: an interim scheme to be used by U.S. Geological Survey: Am. Assoc. Petroleum Geologists Bull., v. 56, no. 6, p. 1128-1133.

Johannsen, Albert, 1939, A descriptive petrography of the igneous rocks, v. 1: Chicago, Univ. Chicago Press, 318 p.

King, E. R., and Zietz, Isidore, 1971, Aeromagnetic study of the Midcontinent Gravity High of central United States: Geol. Soc. American Bull., v. 82, no. 8, p. 2187-2208.

Lane, A. C., 1898, Geological report on Isle Royale, Michigan: Mich. Geol. Survey, v. 6, pt. 1, 281 p. 1911, The Keweenaw series of Michigan: Michigan Geol. and Biol. Survey. Pub. 6, Geol. Ser. 4, 2 vols., 983 p.

Lane, A. C., and Seaman, A. E., 1907, Notes on the geological section of Michigan; Part 1, the pre-Ordovician: Jour. Geol., v. 15, no. 7, p. 680-695.

Lyons, P. L., 1970, Continental and ocean geophysics, in Johnson, Helgi, and Smith, B. L., eds., The megatectonics of continents and oceans: New Brunswick, N. J., Rutgers Univ. Press, p. 147-166.

Palmer, H. C., 1970, Paleomagnetism and correlation of some Middle Keweenawan rocks, Lake Superior: Canadian Jour. Earth Sci., v. 7, no. 6, p. 1410-1436.

Pettijohn, F. J., 1970, The Canadian Shield-A status report, 1970, in Baer, A. J., ed., Basins and geosynclines of the Canadian Shield-symposium, Ottawa, 1970: Canada Geol. Survey Paper 70-40, p. 239-255.

Ross, C. S., 1941, Origin and geometric form of chalcedonyfilled spherulites from Oregon: Am. Mineralogist, v. 26, no. 12, p. 727-732.

Shapiro, Leonard, 1967, Rapid analysis of rocks and minerals by a single-solution method, in Geological Survey research 1967: U.S. Geol. Survey Prof. Paper 575-B, p. 187-191.

Shaw, H. R., and Swanson, D. A., 1970a, Speculations on the fluid mechanical history of Yakima Basalt flows [abs.], in Columbia River Basalt Symposium: 2d, Cheney, Wash. 1969, Proc., p. 330.

1970b, Eruption and flow rates of flood basalts, in Columbia River Basalt Symposium: 2d, Cheney, Wash. 1969, Proc., p. 271-299.

Silver, L. T., and Green, J. C., 1972, Time constants for Keweenawan igneous activity [abs.]: Geol. Soc. America Abstracts with Programs, v. 4, no. 7, p. 665-666.

Tanton, T. L., 1931, Fort William and Port Arthur, and Thunder Cape map areas, Thunder Bay District, Ontario: Canada Geol. Survey Mem. 167, 222 p.

U.S. Geological Survey, 1957, Topographic map of Isle Royale National Park, Michigan (culture revised 1970): scale $1: 62,500$, contour and shaded-relief editions.

Van Hise, C. R., and Leith, C. K., 1911, The geology of the Lake Superior region: U.S. Geol. Survey Mon. 52, 641 p.

White, W. S., 1952, Imbrication and initial dip in a Keweenawan conglomerate bed: Jour. Sed. Petrology, v. 22, no. 4, p. 189-199.

1960, The Keweenawan lavas of Lake Superior, an example of flood basalts: Am. Jour. Sci., v. 258-A, Bradley vol., p. 367-374.

1966a, Tectonics of the Keweenawan Basin, western Lake Superior region: U.S. Geol. Survey Prof. Paper 524-E, $23 \mathrm{p}$.

1966b, Geologic evidence for crustal structure in the western Lake Superior basin, in The earth beneath the continents-a volume of geophysical studies in honor of Merle A. Tuve: Am. Geophys. Union Geophys. Mon. 10 (Natl. Acad. Sci., Natl. Research Council Pub. 1467), p. 28-41. 
1968, The native copper deposits of northern Michigan in Ridge, J. D., ed., Ore deposits of the United States, 1933-1967, v. 1: New York, Am. Inst. Mining, Metall., and Petroleum Engineers, p. 303-326.

1971, Geologic setting of the Michigan copper district, in Soc. Econ. Geologists, Guidebook for field conference, Michigan copper district, 1971: p. 3-17.

1972, The base of the upper Keweenawan, Michigan and Wisconsin: U.S. Geol. Survey, Bull. 1354-F, 23 p.

White, W. S., Brooks, E. R., Hubbard, H. A., Johnson, R. F., and Wilband, J. T., 1971, Keweenawan stratigraphy of westernmost Michigan, in Inst. Lake Superior Geology, 17th Ann., 1971, Abs. and Field Guides: Duluth, Minn., p. 71-72.

White, W. S., Cornwall, H. R., and Swanson, R. W., 1953, Bedrock geology of the Ahmeek quadrangle, Michigan: U.S. Geol. Survey Geol. Quad. Map GQ-27, scale 1:24,000.
White, W. S., and Wright, J. C., 1960, Lithofacies of the Copper Harbor Conglomerate, northern Michigan, in Geological Survey research 1960: U.S. Geol. Survey Prof. Paper 400-B, p. B5-B8.

Winchell, N. H., 1897, Some new features in the geology of northeastern Minnesota: Am. Geologist, v. 20, p. 41-51.

Wold, R. J., and Ostenso, N. A., 1966, Aeromagnetic, gravity, and subbottom profiling studies in Western Lake Superior, in The earth beneath the continents-a volume of geophysical studies in honor of Merle A. Tuve: Am. Geophys. Union Geophys. Mon. 10 (Natl. Acad. Sci., Natl. Research Council Pub. 1467), p. 66-94.

Wolff, R. G., and Huber, N. K., 1973, The Copper Harbor Conglomerate (middle Keweenawan) on Isle Royale, Michigan, and its regional implications: U.S. Geol. Survey Prof. Paper 754-B, 15 p. 


\section{Geology of Isle Royale National Park, Michigan}

GEOLOGICAL SURVEY PR OFESSIONAL PAPER 754

This volume was published as separate chapters $A-C$

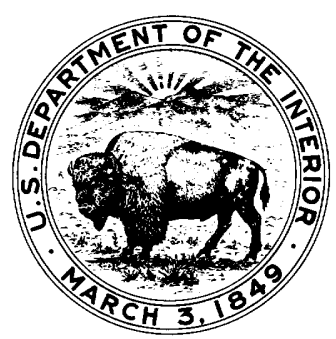




$$
\text { 整 }
$$

UNITED STATES DEPARTMENT OF THE INTERIOR

ROGERS C. B. MORTON, Secretary

\section{GEOLOGICAL SURVEY}

V. E. McKelvey, Director 


\section{CONTENTS}

\section{[Letters designate the separately published chapters]}

(A) Glacial and postglacial geologic history of Isle Royale National Park, Michigan, by N. King Huber.

(B) The Copper Harbor Conglomerate (middle Keweenawan) on Isle Royale, Michigan, and its regional implications, by Roger G. Wolff and N. King Huber.

(C) The Portage Lake Volcanics (middle Keweenawan) on Isle Royale, Michigan, by N. King Huber. 

